\title{
Environmental Restoration Quality Program Plan
}

\author{
Environmental Restoration Program
}

P.O. Box 2003

Oak Ridge, Tennessee 37831-7298

Date Issued-August 1992

\section{Prepared for}

U.S. Department of Energy

Office of Environmental Restoration and Waste Management under budget and reporting code EW 20

\section{MARTIN MARIETTA ENERGY SYSTEMS, INC.}

managing the

Oak Ridge K-25 Site

Oak Ridge Y-12 Plant

Oak Ridge National Laboratory

under contract DE-AC05-84OR21400
Paducah Gaseous Diffusion Plant Portsmouth Gaseous Difiusion Plant under contract DE-AC05-76OR00001

for the

U.S. DEPARTMENT OF ENERGY

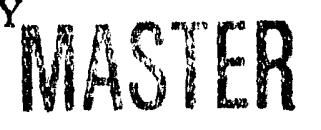




\section{Approvals \\ Environmental Restoration Quality Program Plan \\ (ES/ER/TM-A/R2)}

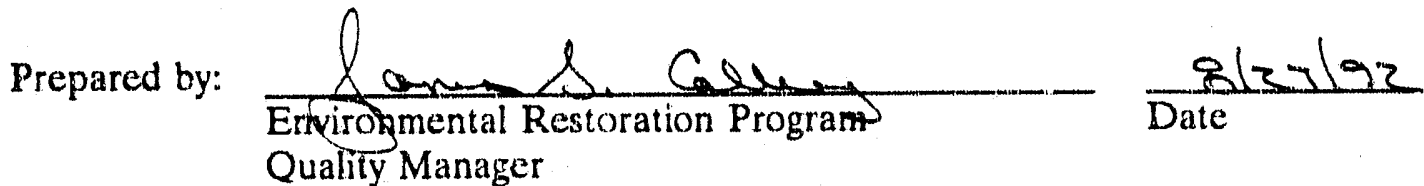

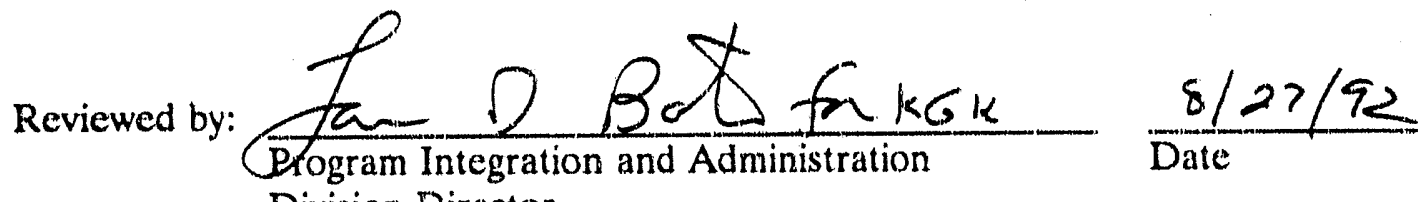

Division Director

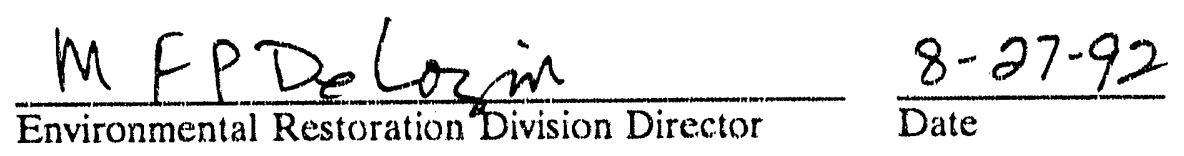

Approved by:
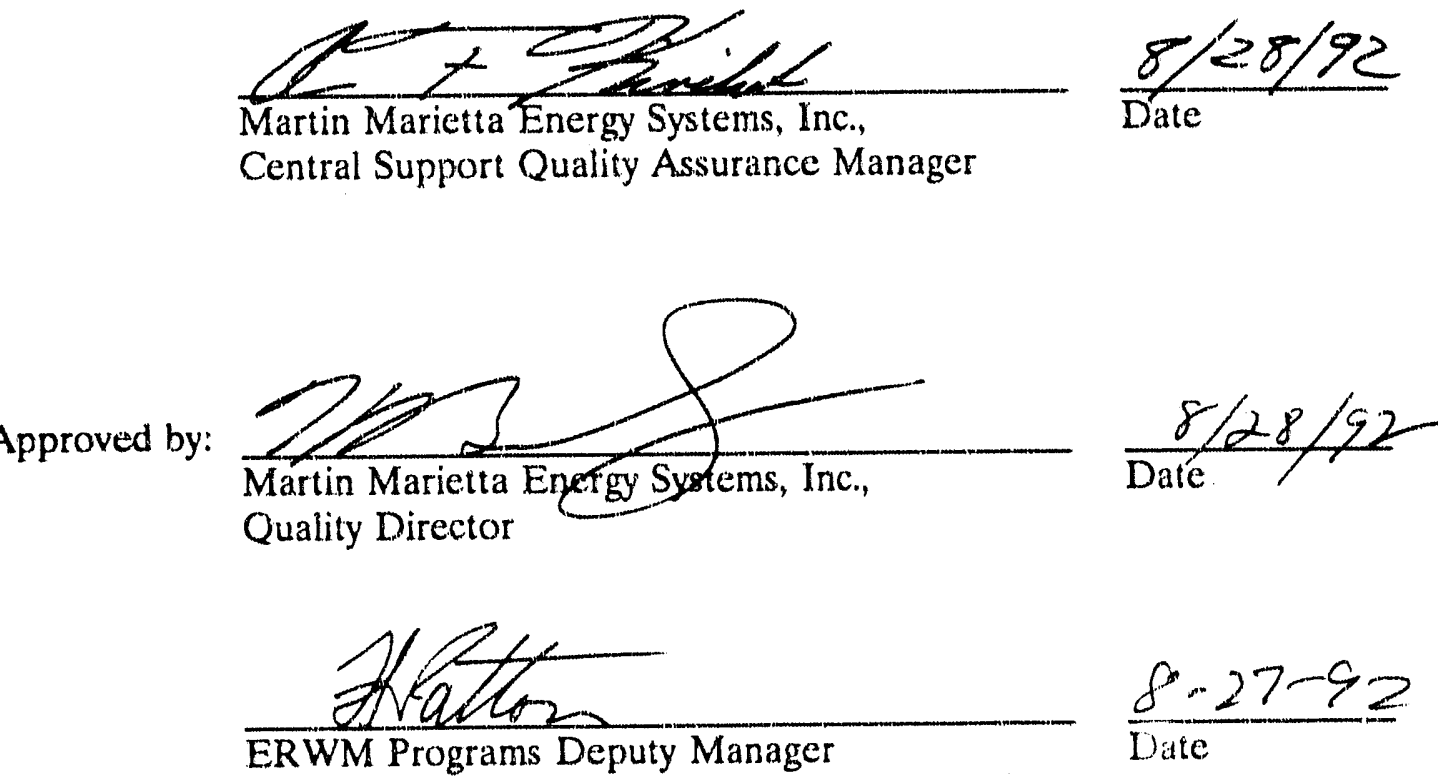


\section{CONTENTS}

EXECUTTVE SUMMARY $\ldots \ldots \ldots \ldots \ldots \ldots \ldots \ldots \ldots \ldots \ldots \ldots \ldots \ldots \ldots \ldots$

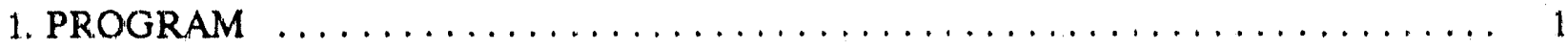

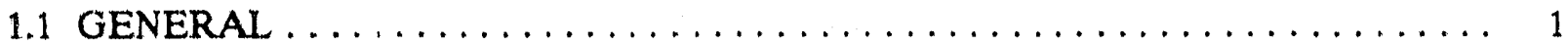

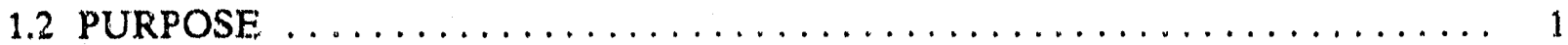

1.3 SCOPE ...................................... 2

1.4 SOURCE AND APPLICATION OF QUALITY ASSURANCE REQUIREMENTS . 2

1.5 ORGANIZATION AND PROGRAM RESPONSIBILITIES $\ldots \ldots \ldots \ldots \ldots \ldots 6$

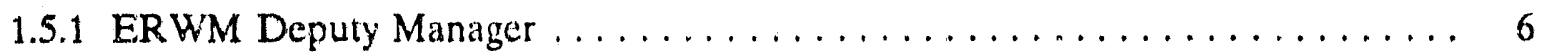

1.5.2 ER and PI\&A Division Directors $\ldots \ldots \ldots \ldots \ldots \ldots \ldots \ldots \ldots \ldots, 6$

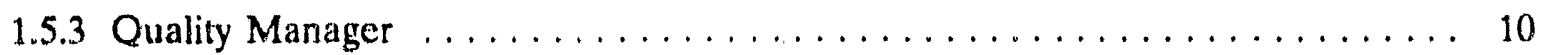

1.5.4 Quality Assurance Specialist .......................... 11

1.5.5 Site Remedial Action Program Managers ................... 11

1.5.6 Central D\&D Program Director and Coordinators $\ldots \ldots \ldots \ldots \ldots \ldots \ldots$ i2

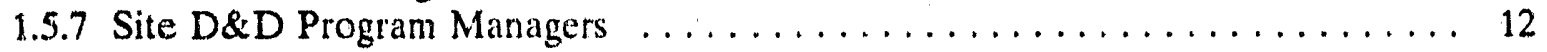

1.5 .8 Functional Managers $\ldots \ldots \ldots \ldots \ldots \ldots \ldots \ldots \ldots \ldots \ldots \ldots \ldots \ldots \ldots, 12$

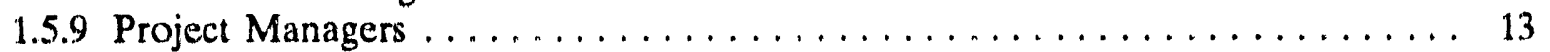

1.5.10 Project Organization $\ldots \ldots \ldots \ldots \ldots \ldots \ldots \ldots \ldots \ldots \ldots \ldots \ldots$

1.6 QUALITY ASSURANCE PROGRAM AND PROJECT REQUIREMENTS $\ldots \ldots, 14$

1.6.1 Program Requirements............................ 14

1.6.2 Project Quality Assurance Plan Requirements $\ldots \ldots \ldots \ldots \ldots \ldots \ldots$

2. TRAINING AND QUALIFICATION $\ldots \ldots \ldots \ldots \ldots \ldots \ldots \ldots \ldots \ldots \ldots$

2.1 GENERAL .......................................... 19

2.1 TRAINING NEEDS ASSESSMENT $\ldots \ldots \ldots \ldots \ldots \ldots \ldots \ldots \ldots \ldots, 19$

2.2 TRAINING PROGRAM IMPLEMENTATION $\ldots \ldots \ldots \ldots \ldots \ldots \ldots \ldots \ldots$

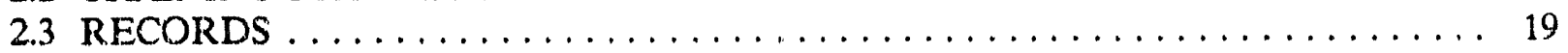

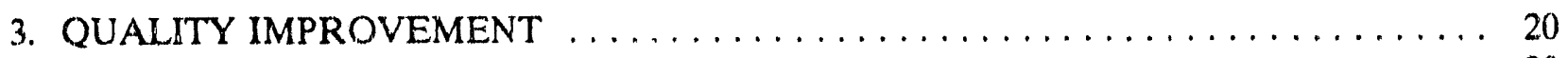

3.1 GENERAL ....................................... 20

3.2 CONTROL OF NONCONFORMING ITEMS $\ldots \ldots \ldots \ldots \ldots \ldots \ldots \ldots \ldots 20$

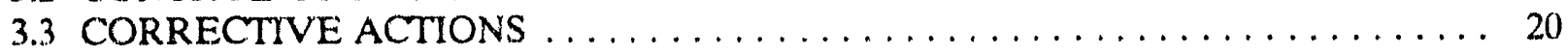

3.4 EVALUATION OF CORRECTIVE ACTION ITEMS ................ 21

4. DOCUMENTS AND RECORDS $\ldots \ldots \ldots \ldots \ldots \ldots \ldots \ldots \ldots \ldots \ldots \ldots \ldots \ldots \ldots \ldots \ldots, 22$

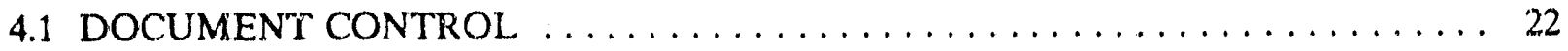

4.1.1 Controlled Documents ............................ 22

4.1.2 QA Project Plan Document Control ..................... 22

4.2 QUALITY ASSURANCE RECORDS $\ldots \ldots \ldots \ldots \ldots \ldots \ldots \ldots \ldots \ldots \ldots$

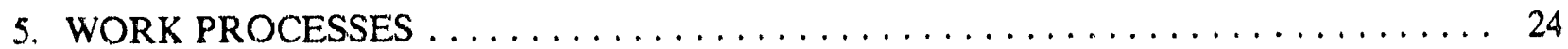

5.1 INSTRUCTIONS, PROCEDURES, AND DRAWINGS $\ldots \ldots \ldots \ldots \ldots \ldots \ldots 24$

5.2 IDENTIFICATION AND CONTROL OF ITEMS $\ldots \ldots \ldots \ldots \ldots \ldots \ldots \ldots 24$

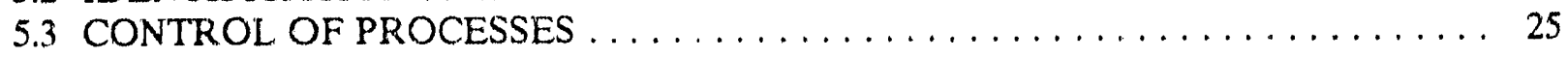




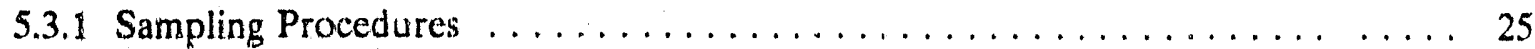

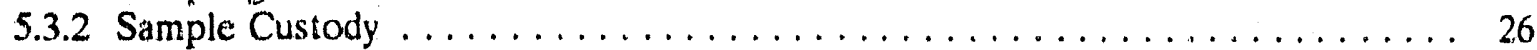

5.3 .3 Analytical Procedures . . . . . . . . . . . . . . . . . . . . 27

5.4 CONTROL OF MEASURING AND TESTING EQUIPMENT $\ldots \ldots \ldots \ldots \ldots \ldots$

5.5 HANDLING, STORAGE, AND SHIPPING $\ldots \ldots \ldots \ldots \ldots \ldots \ldots \ldots \ldots$

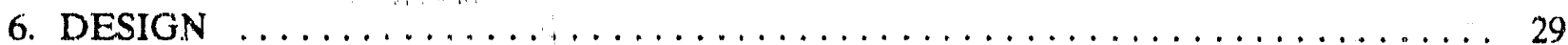

6.1 DESIGN CONTROL .............................. 29

6.1.1 Quality Assurance Objectives for Measurement Data . . . . . . . . . . . . . . 29

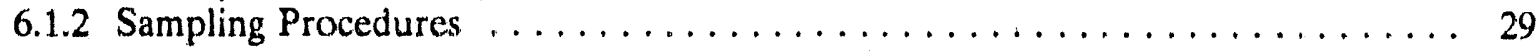

6.1 .3 Analytical Procedures . . . . . . . . . . . . . . . . . . . . . . 29

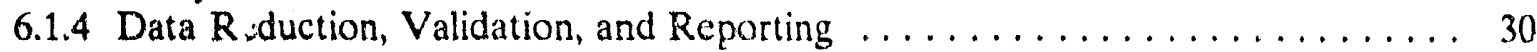

6.1.5 Internal Quality Control Checks and Frequency $\ldots \ldots \ldots \ldots \ldots \ldots \ldots \ldots \ldots$

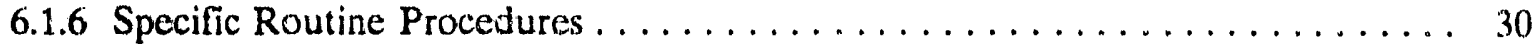

6.1 .7 Automated Data Processing Software $\ldots \ldots \ldots \ldots \ldots \ldots \ldots \ldots \ldots \ldots$

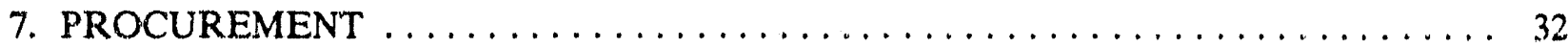

7.1 PROCUREMENT-DOCUMENT CONTROL $\ldots \ldots \ldots \ldots \ldots \ldots \ldots \ldots \ldots \ldots$

7.2 CONTROL OF PURCHASED ITEMS AND SERVICES $\ldots \ldots \ldots \ldots \ldots \ldots \ldots$

8. INSPECTION AND ACCEPTANCE TESTING $\ldots \ldots \ldots \ldots \ldots \ldots \ldots \ldots \ldots \ldots$

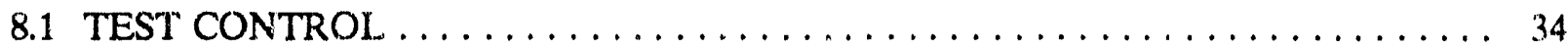

8.2 INSPECTION, TESTING, AND DPERATING STATUS $\ldots \ldots \ldots \ldots \ldots \ldots \ldots$

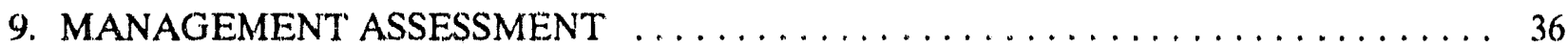

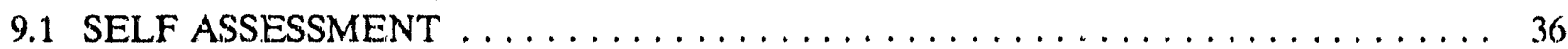

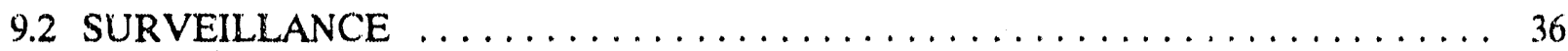

9.3 FIELD AUDITS AND SURVEILLANCES $\ldots \ldots \ldots \ldots \ldots \ldots \ldots \ldots \ldots \ldots \ldots$

9.4 ANALYTICAL LABORATORY AUDITS AND SURVEILLANCES . . . . . . . 37

9.5 OPERATIONAL READINESS PROCESS $\ldots \ldots \ldots \ldots \ldots \ldots \ldots \ldots \ldots \ldots \ldots$

9.6 RISK ASSESSMENT $\ldots \ldots \ldots \ldots \ldots \ldots \ldots \ldots \ldots \ldots \ldots \ldots \ldots \ldots \ldots \ldots$

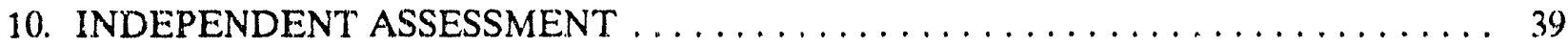

10.1 AUDITS AND SURVEILLANCES $\ldots \ldots \ldots \ldots \ldots \ldots \ldots \ldots \ldots \ldots \ldots \ldots$

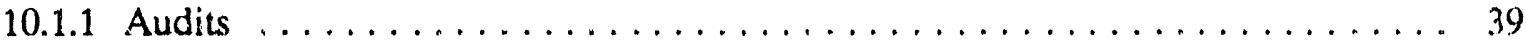

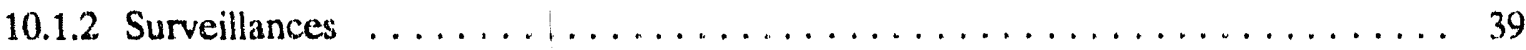

10.1.3 Field and Laboratory Audits and Surveillance . . . . . . . . . . . . . 39

REFERENCES $\ldots \ldots \ldots \ldots \ldots \ldots \ldots \ldots \ldots \ldots \ldots \ldots \ldots \ldots \ldots \ldots \ldots \ldots \ldots$ 


\section{EXECUTIVE SUMMARY}

The Martin Marietta Energy Systems, Inc., Environmental Restoration (ER) Quality Program Plan (QPP) has been developed in compliance with DOE Order 5700.6C, "Quality Assurance." This plan is based on the Energy Systems Quality Program Plan (Y/QD-15 Rei 0) (Energy Systems 1992b). It specifies that, beyond requirements explicitly identified in the plan itself, applicable standards and procedures identified in Policy, Standards And Procedures Manual, Martin Marietta Energy Systems, Inc. (Energy Systems 1991b) shall be applied.

This ER QPP is designed to meet the requirements of the Energy Systems QPP and the specifications of the Energy Systems quality procedures contained in Volume 4 of Policy, Standards and Procedures Manual, Martin Marietta Energy Systems, Inc. (Energy Systems 1991b). It combines the requirements of the American Society Of Mechanical Engineers document Quality Assurance Program Requirements for Nuclear Facilities (ASME NQA-1) (ASME 1989a) with the software Quality Assurance (QA) requirements from Quality Assurance Requirements for Nuclear Facility Applications (ASME NQA-2) (AiME 1989b). Also included is the U.S. Environmental Protection Agency (EPA) guidance established in Interim Guidelines and Specifications for Preparing Quality Assurance Project Plans (EPA-600/4-83-004, QAMS-005/80) (Stanley and Verner 1983), EPA guidance for Data Quality Objectives for Remedial Response Activities (EPA-540/G87/003A, OSWER Directive 9335.0-7B) (EPA 1987), and Risk Assessment Guidance for Superfund, Volume I: Human Health Evaluation Manual (Part A) (EPA/540/1-89/002) (EPA 1989). The plan also provides for compliance with DOE orders 4700.1, "Project Management System;" 5000.3A, "Occurrence Reporting and Processing of Operations Information;" 1324.2, "Records Distribution;" and DOE/ORO 931, Management Plan for the Oak Ridge Operations Environmental Restoration Program (DOE 1991a).

Specifically, the plan identifies the chain of command for executing Quality requirements and the responsibilities of ER Program staff identified in that hierarchy. Those staff members, include the Deputy Director of Environmental Restoration and Waste Management (ERWM), the ER Division Director, The Program Integration and Administration Division Director, the Quality Manager (matrixed from the Energy Systems Central Support QA organization), QA specialists, site program managers, the Decontamination and Decornmissioning (D\&D) Program Manager, functional managers, and activity-specific project managers and organizations. This QPP also applies to those Energy Systems organizations, contractors, and subcontractors performing work for the ER Program.

The ER QPP will be supplemented by QA Project Plans (QAPjPs) to be developed for each ER investigative, monitoring, measuring, or remediation project operated by Energy Systems or its subcontractors. The format and requirements of the QAPjPs will be based on QAMS $005 / 80$ and will be tailored to the needs and requirements of the activity-specific project. QAPjPs also will meet the requirements of the pertinent Comprehensive Environmental Response, Compensation, and Liability Act (CERCLA) and Resource Conservation and Recovery Act (RCRA) guidance. ER Program activities that do not require the application of QAMS-005/80 will be supplemented by QA plans that adhere to the applicable NQA-1 requirements of this QPP. 


\section{PROGRAM}

\subsection{GENERAL}

The Martin Marietta Energy Systems, Inc., Environmental Restoration (ER) Program was initially chartered on October 1, 1989, as a "Central Environmental Restoration Division" to manage the investigation and remediation of inactive sites and facilities that have been declared surplus and have no further programmatic use. The Energy Systems ER Division was established to support the DOE Oak Ridge Field Office (DOE-OR) consolidated ER Program.

The DOE-OR Assistant Manager for Environmental Restoration and Waste Management provides program and budget direction to the Energy Systems ER Program for environmental restoration activities at the sites operated by Energy Systems (Oak Ridge K-25 Site, Oak Ridge National Laboratory, Oak Ridge Y-12 Plant, Paducah Gaseous Diffusion Plant, Portsmouth Gaseous Diffusion Plant) and at the off-site locations. The Energy Systems ER Division is specifically charged with assessing these sites for potential contamination and managing the cleanup processes. The Energy Systems Environmental Restoration Division was chartered on October 1,1989, as a central organization to manage the Remedial Action (RA) Program. A February 11, 1992, reorganization created the Environmental Restoration and Waste Management (ERWM) organization, which integrated the activities of the ER Division and the Decontamination and Decommissioning (D\&D) Division and the Central Wasie Management Division. Management of Central D\&D and RA Programs is now the responsibility of the ER Division. Technical and administrative support and management systems support for the ER Program is provided by the Program Integration and Administration (PI\&A) Division.

\subsection{PURPOSE}

The purpose of this document is to ensure that:

- senior ER management provides planning, organization, direction, control, and support to achieve the organization's objectives;

- the line organization achieves quality; and

- overall performance is reviewed and evaluated using a rigorous assessment process.

This document defines the ER Quality Program, identifies requirements, assigns responsibilities for ensuring that program objectives are achieved as planned, and describes or references the controls, Quality procedures, and guidelines to be followed during environmental investigation, clean up, and reporting activities. This quality program is based on the American Society of Mechanical Engineers (ASME) Quality Assurance Program Requirements for Nuclear Facilities (NQA-1) (ASME 1989a) and incorporates requirements from the Environmental Protection Agency (EPA) Guidance for Conducting Remedial Investigations and Feasibility Studies Under CERCLA (EPA/540/G-89/004, OSWER Directive 9355.3-01) (EPA 1988) and EPA OSWER Directive 9502.00-6D, RCRA Facility Investigation 
(RFI) Guidance (EPA 530/SW/89031) (EPA 1989), which both require that environmental Quality Assurance (QA) and quality control (QC) plans and procedures be based on EPA-600/4-83-004 (QAMS-005/80), Interim Guidelines and Specifications for preparing Quality Assurance Project Plans (EPA 1983).

\section{$1.3 \mathrm{SCOPE}$}

This Quality Program Plan (QPP) applies to the ERWM organizations directly responsible for implementing ER Program activities (i.e., ER and PI\&A Divisions) and to Energy Systems organizations supporting the ER Program at the five sites operated by Energy Systems and at the off-site locations, including all contractors and subcontractors under the auspices of the ER Program. Control of work activities affecting quality will be maintained throughout the life of the program to the degree necessary to ensure that quality objectives are met.

This document merges the requirements of NQA-1 with those of QAMS 005/80 and provides for their implementation. The procedures required to implement this QPP are described or referred to by title and document number in the text, or their preparation has been required. Figure 1.1 shows the relationship between this QPP, DOE Order $5700.6 \mathrm{C}$, NQA-1, and QAMS-005/80. The numbers in the first column of Table 1.1 designate the sections of this document where the applicable NQA-1 and/or QAMS 005/80 element requirements are delineated. For example, Sect. 1.6.2.2.1 describes the requirements of element 3, Project Description, of QAMS 005/80. All clements of QAMS 005/80 and NQA-1 are addressed within this QPP, and each element of QAMS 005/80 is associated with the corresponding element of NQA-1.

\subsection{SOURCE AND APPLICATION OF QUALITY ASSURANCE REQUIREMENTS}

The QPP elements identified in this document were derived from the requirements identified in QAMS-005/80 and in Volume 4 of Policy, Standards and Procedures Manual, Martin Marietta Energy Systems, Inc., which addresses the requirements of NQA-1 and the software requirements of NQA-2. This plan also addresses applicable DOE and EPA Quality Assurance requirements. Figure 1.2 depicts the flowdown of DOE, ASME, EPA, and Energy Systems Quality Assurance requirements to the ER QPP.

The format of the ER QPP is based on DOE Order $5700.6 \mathrm{C}$ and utilizes the requirements of NQA-1 and QAMS-005/80. The format and requirements of QA Project Plans (QAPjPs) will be based on the elements of QAMS-005/80 and will include other elements of the ER QPP as needed. 


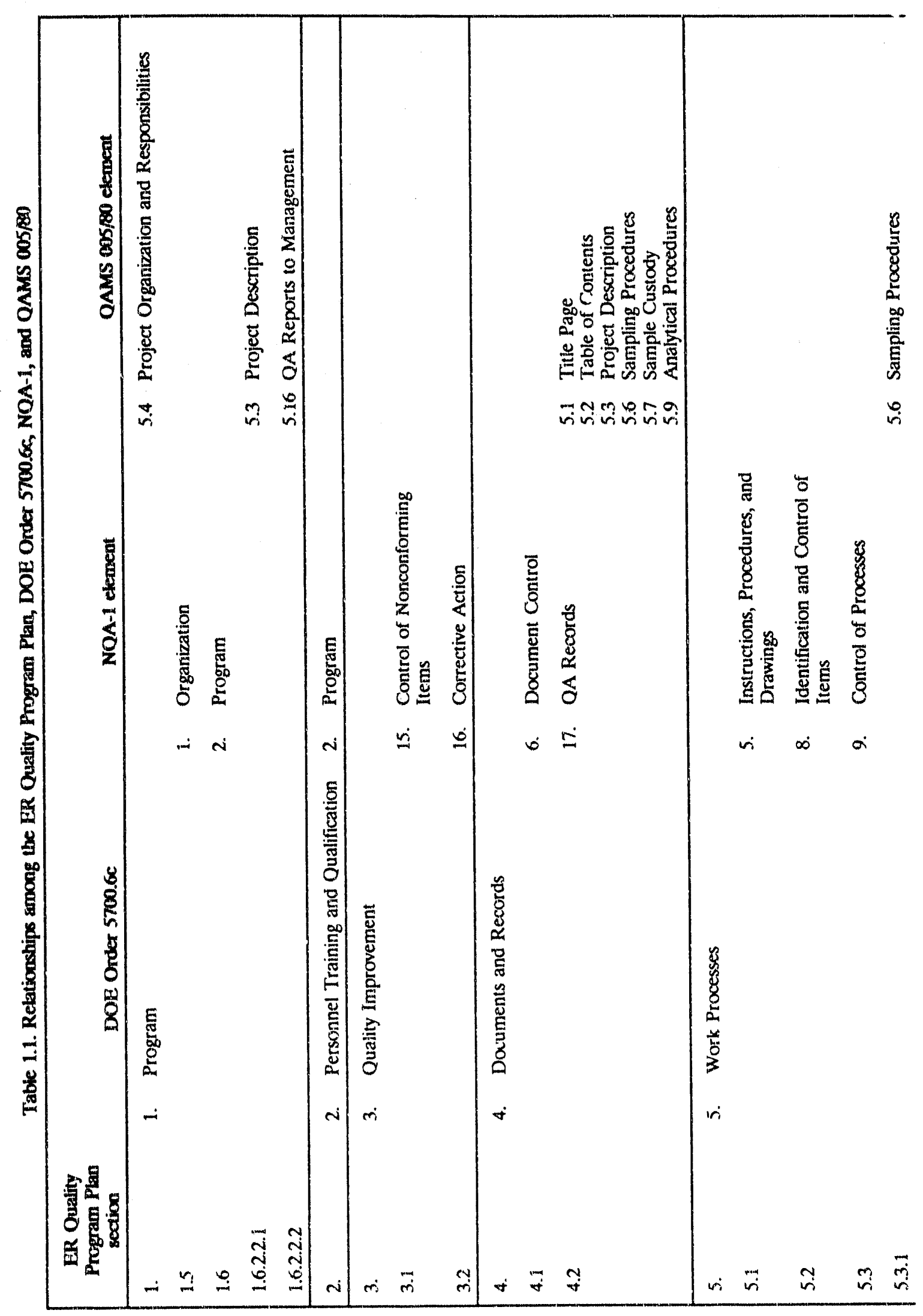




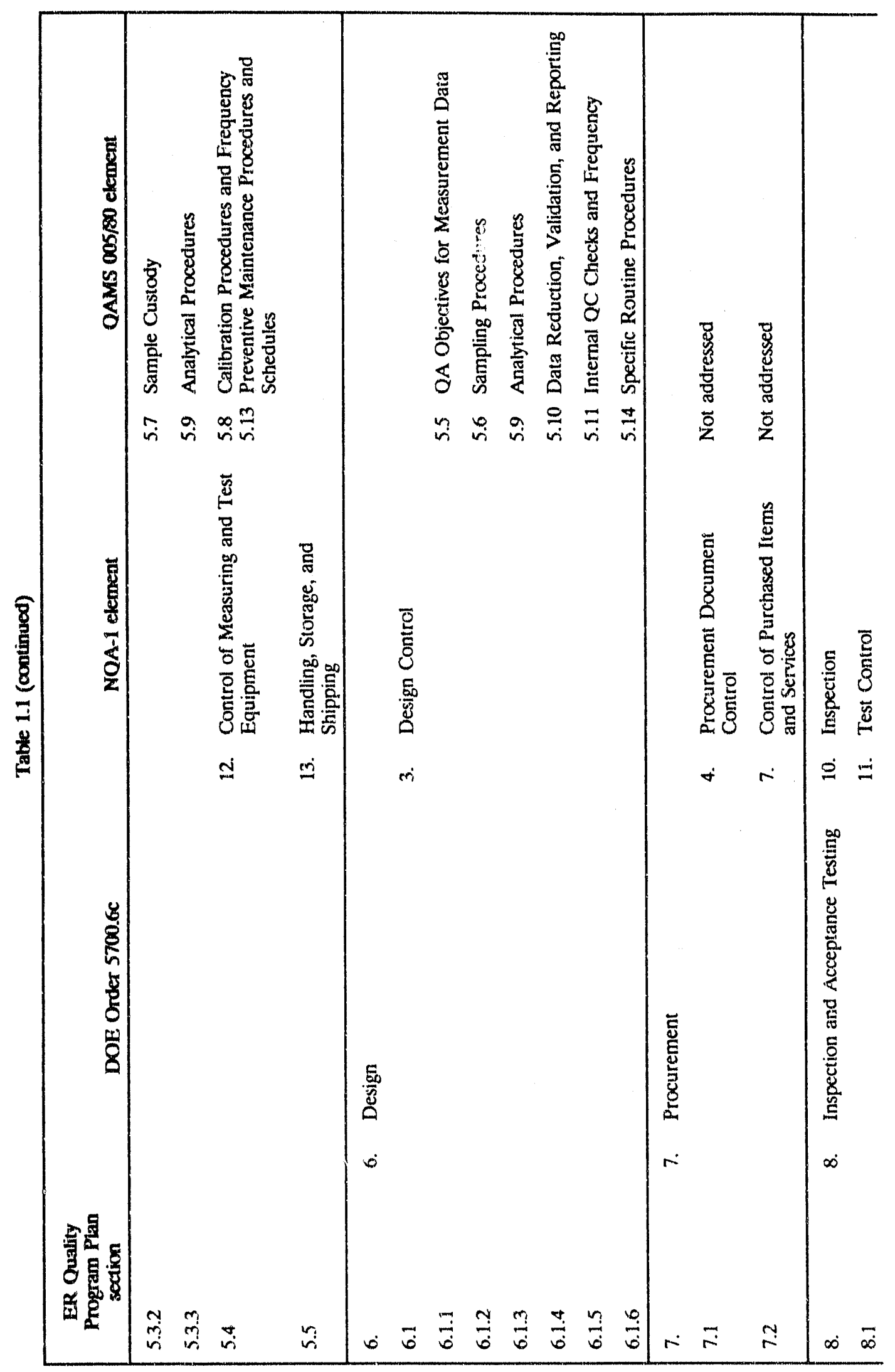


. 


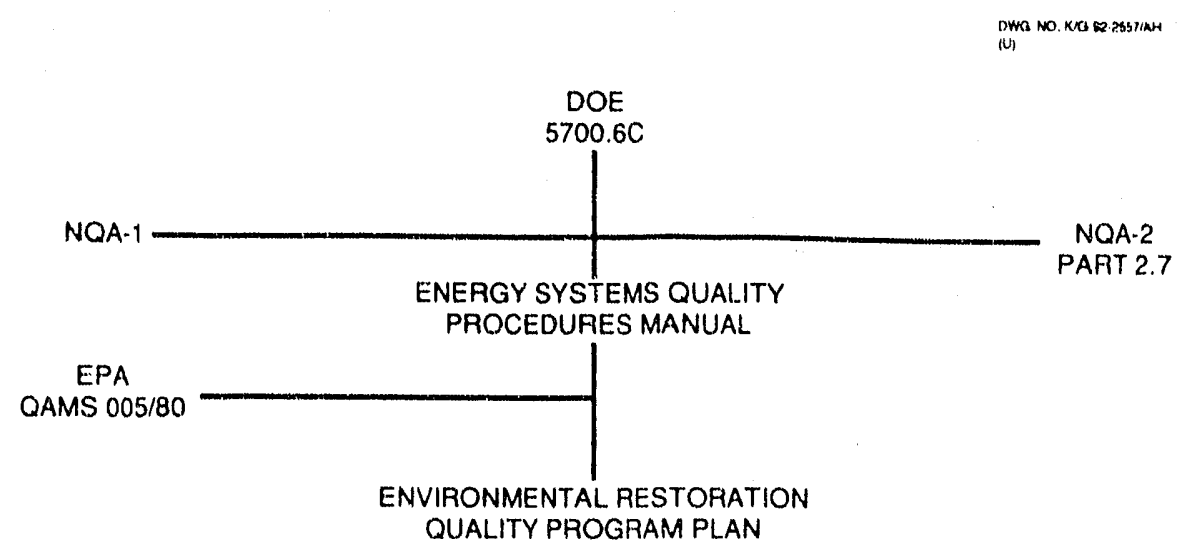

Fig. 1.2 Flowdown of Environmental Restoration Program quality assurance requirements.

\subsection{ORGANIZATION AND PROGRAM RESPONSIBILITIES}

Figures 1.3 through 1.5 are organizational charts for the ER Program. For increased efficiency, support elements, including Quality support, are matrixed from Energy Systems organizations. The ER Program Quality Manager is matrixed from the Energy Systems Central Support Quality organization. The Quality Manager reports administratively to the Energy Systems Quality Director through the Central Support Quality Manager. QA specialists assigned to provide support to the ER Program report functionally to the ER site program managers and administratively to the ER Program Quality Manager for policy and guidance. ER Program quality responsibilities are delineated in Sects. 1.5.1 through 1.5.9.

\subsubsection{ERWM Deputy Manager}

The Deputy Manager of ERWM is responsible for:

- ensuring that the ER Program activities are performed in accordance with all applicable DOE orders, EPA regulations, and other requirements governing the accomplishment of ER technical activities and

- ensuring that the requirements of this QPP are implemented for applicable ER Program activities.

\subsubsection{ER and PI\&A Division Directors}

The division directors are responsible for:

- establishing and documenting roles and responsibilities of their division personnel,

- establishing and documenting internal and external interfaces of personnel involved with ER program activities,

- establishing and maintaining the ER Quality Program and developing the implementing procedures, 


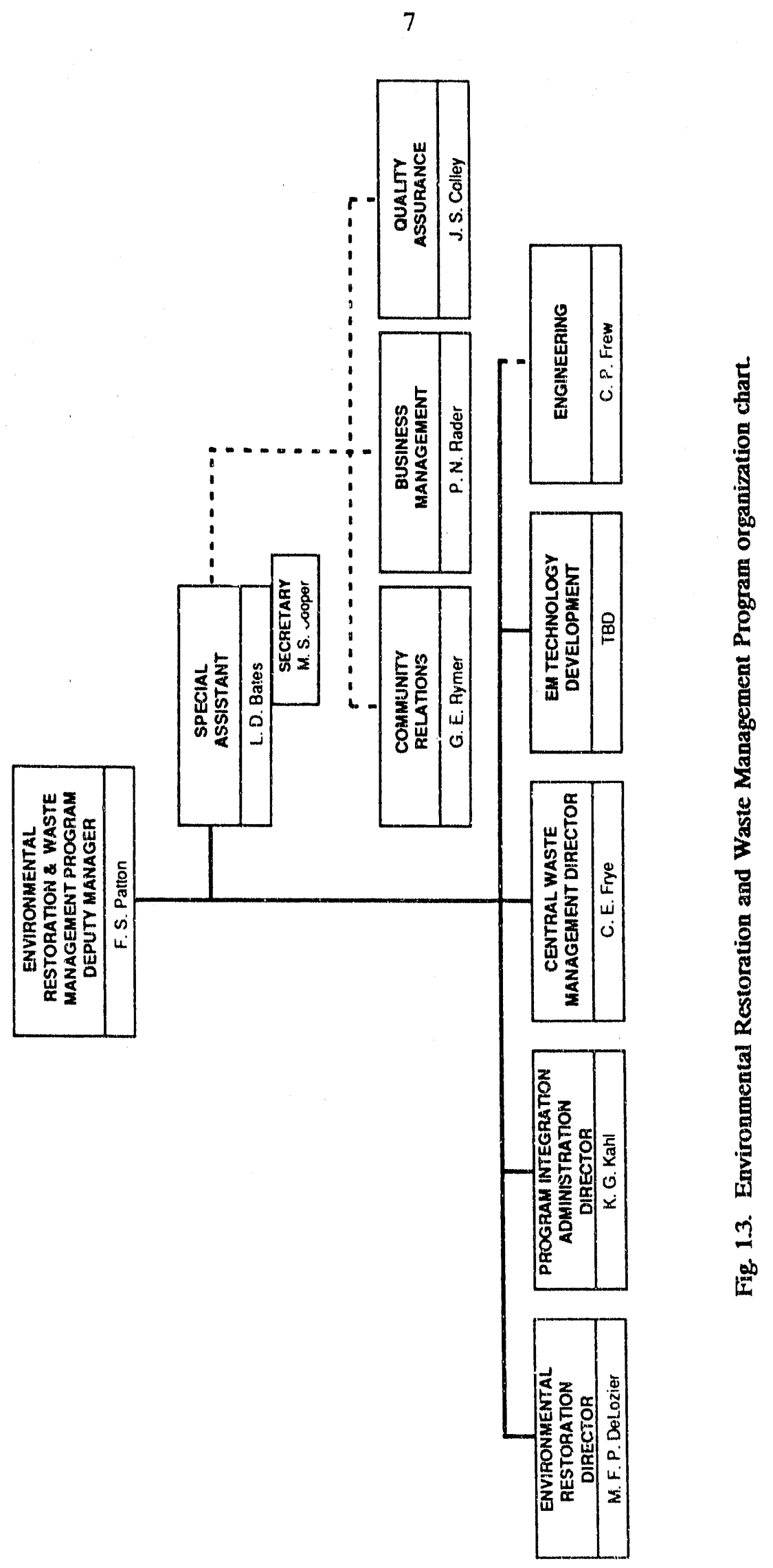




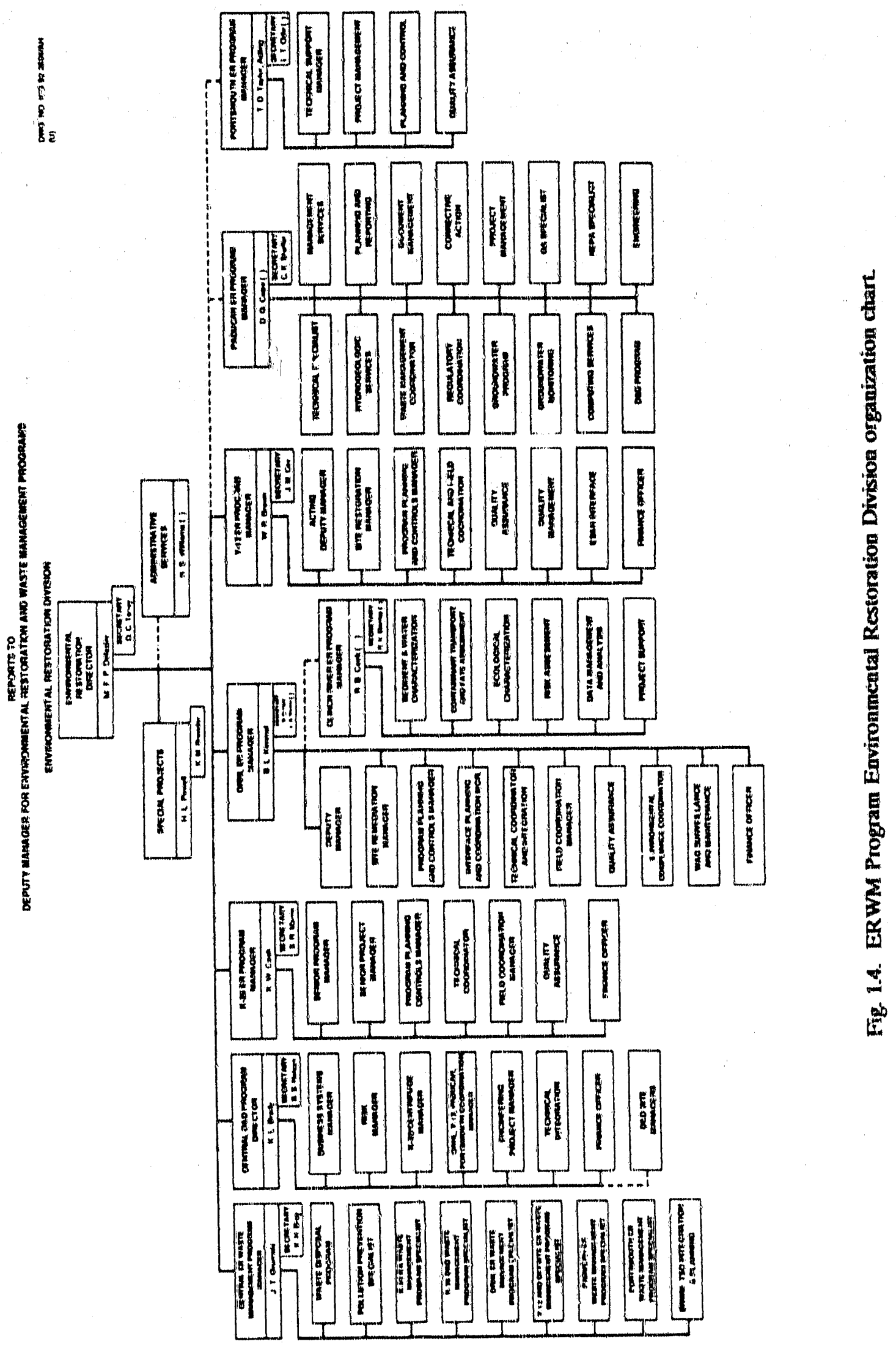


g
D
总

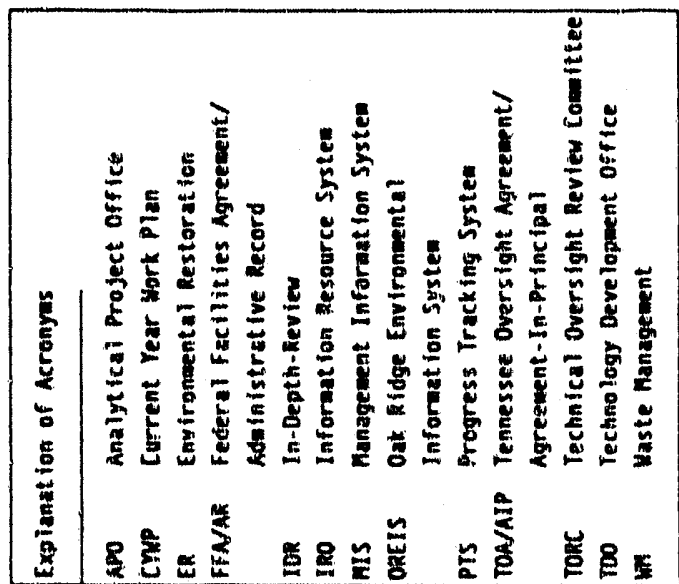

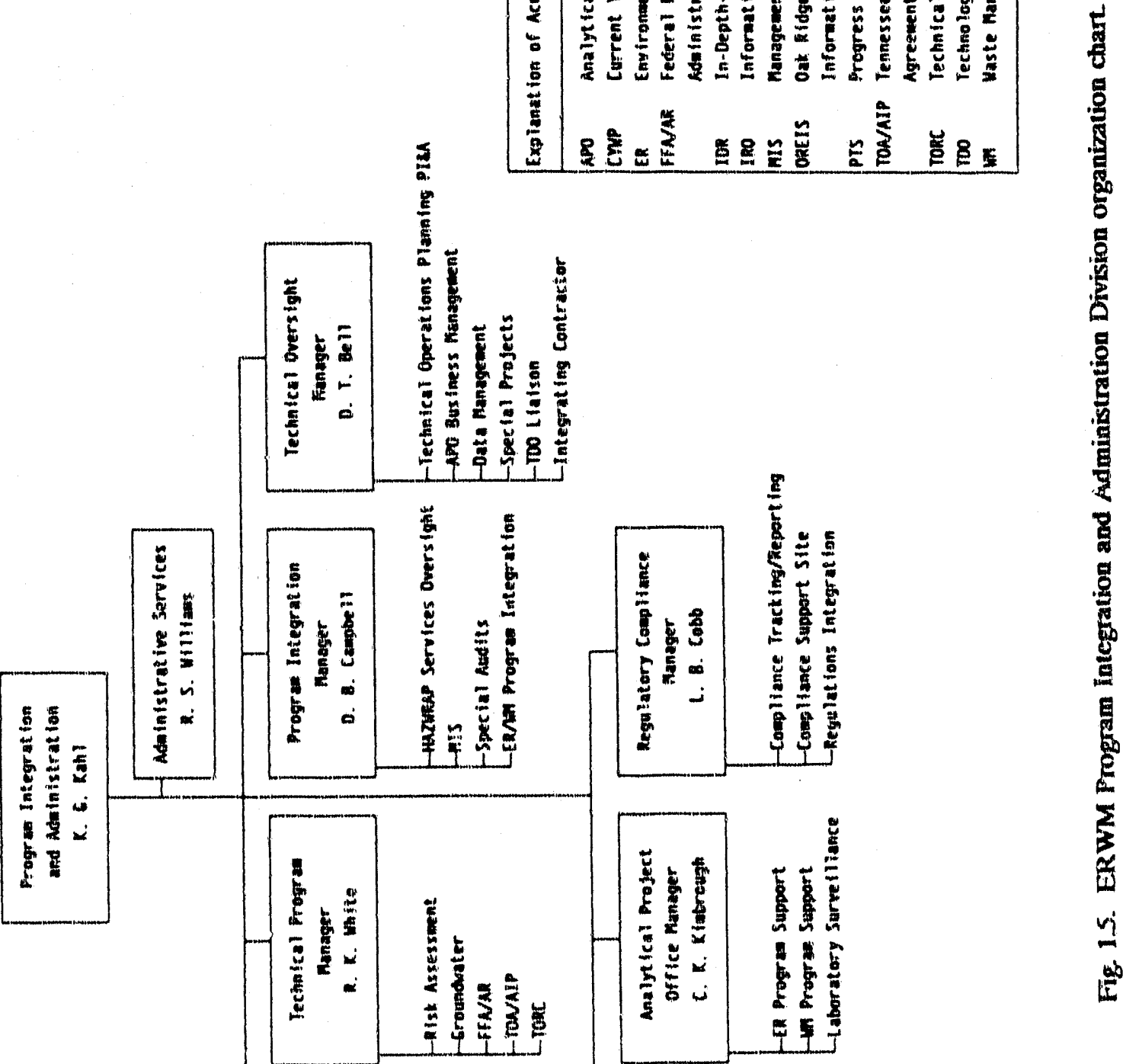

3
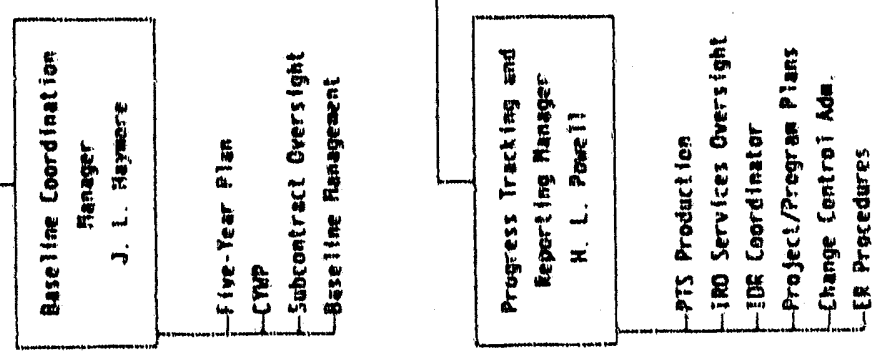
- establishing a performance-based training program for ER program personnel,

- ensuring effective audits or surveillances of Quality program activities,

- approving and funding activities required by the Quality program, and

- establishing and conducting a self-assessment program.

\subsubsection{Quality Manager}

The ER Program Quality Manager reports functionally to the Deputy Manager level of ERWM and is responsible for:

- assisting in the development of the quality program;

- evaluating the effectiveness of the quality program through audits and surveillances;

- advising the division directors and line and staff functional managers on quality matters;

- assisting in the development of ER Program procedures, instructions, and standards in support of programs and projects;

- ensuring that the quality training and awareness program is established;

- maintaining this QPP;

- ensuring that nonconformances and reportable occurrences are tracked and assisting in the resolution of quality problems;

- ensuring that quality measures are implemented to reduce conditions adverse to the success of ER Program activities;

- evaluating the QA/QC programs of potential subcontractors for conformance to ER Program QA/QC requirements;

- ensuring that $\mathrm{QA} / \mathrm{QC}$ requirements are included in subcontracts for ER activities; and

- evaluating the effectiveness of subcontractor quality programs through audits and surveillances.

The ER Program Quality Manager formulates and directs the quality program and has sufficient personnel, authority, access to work areas, and organizational freedom to:

- verify implementation of the Quality program;

- identify problems;

- identify, recommend, or provide solutions to problems;

- verify implementation of solutions;

- in cases where unsatisfactory conditions are discovered, ensure that further processing, delivery, installation, or use of the affected item or service is controlled until proper disposition can be made; and

- stop work when the severity of conditions adverse to quality warrant such action. 


\subsubsection{Quality Assurance Specialist}

The ER Program QA specialist reports functionally to an ER site program manager and is responsible for:

- helping the assigned ER site program manager prepare procedures and documents to establish and implement the Quality Program in accordance with this document;

- evaluating the effectiveness of QA activities in the ER Program through scheduled audits and surveillance and reporting results to the Quality Manager and the responsible ER site program manager;

- promoting ER Program quality and awareness programs and attending training sessions to enhance skills;

- providing guidance to resolve quality problems and ensuring that corrective action is taken and appropriately documented in response to occurrence reports, nonconformance reports, and so forth;

- helping ER Program management track corrective actions and analyze data pertaining to quality;

- participating in ER Program readiness reviews;

- participating as a member of the project team;

- providing advice and recommendations to the ER Program Quality Manager on Quality Program anomalies;

- identifying areas where improvement could benefit the ER Program; and

- initiating stop-work actions when the severity of conditions adverse to quality warrants immediate action.

\subsubsection{Site Remedial Action Program Managers}

The site RA program managers are responsible for:

- ensuring that applicable Quality requirements are met;

- ensuring the quality of assigned work;

- ensuring that any necessary detailed operating procedures are developed to establish and maintain consistency of program activities;

- ensuring that operating procedures are effectively implemented;

- ensuring that appropriate $Q A / Q C$ requirements are included in subcontracts and that subcontraci technical commitments are met;

- ensuring that quality-related issues and problems are promptly identified and corrected;

- ensuring that applicable state and federal codes, standards, and regulations are appropriately specified and effectively implemented;

- interfacing with and directing (except for independent oversight) the activities of the assigned ER QA specialist on all quality-related matters; 
- implementing training plans by assessing training needs, scheduling necessary training, and ensuring that training is completed and documented;

- implementing continual quality improvements as appropriate in assigned work areas; and

- stopping work when the severity of conditions adverse to quality warrants such action.

\subsubsection{Central D\&D Program Director and Coordinators}

The Central D\&D Program Director and Coordinators are responsible for

- implementing the ER Quality Program for their assigned areas;

- ensuring that operating procedures are effectively implemented;

- ensuring that applicable Quality requirements are met;

- ensuring that training plans are developed, implemented, and evaluated for assigned personnel;

- interfacing with the ER Quality Manager on all quality-related matters; and

- initiating stop-work action when the severity of conditions adverse to quality warrants immediate action.

\subsubsection{Site D\&D Program Managers}

The D\&D site program managers

- ensure that applicable QA requirements are met;

- ensure the quality of assigned work;

- ensure that any necessary detailed operating procedures are developed to establish and maintain consistency of program activities;

- ensure that operating procedures are effectively implemented;

- ensure that appropriate $\mathrm{QA} / \mathrm{QC}$ requirements are included in subcontracts and that subcontract technical commitments are met;

- ensure that quality-related issues and problems are promptly identified and corrected;

- ensure that applicable state and federal codes, standards, and regulations are appropriately specified and effectively implemented;

- interface with the QA specialist on all quality-related matters;

- implement training plans by assessing training needs, scheduling necessary training, and ensuring that training is completed and documented; and

- initiate stop-work action when the severity of conditions adverse to quality warrants such action.

\subsubsection{Functional Managers}

Functional managers may report to a project manager or a site program manager. They are responsible for: 
- including the appropriate QA requirements of this document in all evaluation, planning, investigative, analytical, and reporting activities of ER projects;

- consulting with the ER Quality Manager on all quality-related matiers;

- investigating quality problems, determining their root causes, proposing solutions, implementing corrective actions, and obtaining the concurrence of the ER Quality Manager on the appropriateness of the corrective action;

- ensuring that documents prepared by or for the ER Program, such as QAPjPs, health and safety plans, work plans, and investigation reports, are submitted to the appropriate organizations and persons for review, comment, and approval;

- specifying the appropriate QA/QC requirements in subcontracts;

- implementing cost-effective quality improvements; and

- recommending stop-work action when the severity of conditions adverse to quality warrants immediate action.

\subsubsection{Project Managers}

Project managers typically report to site program managers or functional managers. They are responsible for:

- including the appropriate QA requirements of this document in all planning, investigative, analytical, and reporting activities of ER projects;

- including the QA specialist on the project teams;

- consulting with the QA specialist on all quality-related matters;

- investigating quality problems, determining their root causes, proposing solutions, implementing corrective actions, and obtaining the concurrence of the QA specialist on the appropriateness of the corrective action;

- initiating stop-work actions when the severity of conditions adverse to quality warrants immediate action;

- submitting the appropriate documents (such as QAPJPs, health and safety plans, work plans, and investigation reports) to the QA specialist for comment and approval;

- conducting operational readiness reviews according to GP-24, "Operational Readiness Process" (Energy Systems 1990)

- specifying the appropriate $\mathrm{QA} / \mathrm{QC}$ requirements in subcontracts; and

- implementing cost-effective quality improvements.

\subsubsection{Project Organization}

A table or chart showing the organizations and lines of authority of key projects will be included in QAPjPs. As a minimum, the following personnel shall be included.

- The ER site program manager

- The ER project manager 
- The site health and safety officer

- The site project manager

- The environmental laboratory manager

- The QA specialist

- The ER waste disposal cocrdinator

- Health physics personnel

- Industrial hygiene personnel

- Statistical services personnel

Project personnel QA responsibilities are as follows.

- Ensuring that applicable Quality requirements are met

- Ensuring the quality of assigned work

- Ensuring that operating procedures are identified, required, and effectively implemented

- Ensuring that appropriate QA/QC requirements are included in subcontracts and internal work authorizations and that subcontract technical commitments are met

- Ensuring that quality-related issues and problems are promptly identified and corrected

- Ensuring that applicable state and federal codes, standards, and regulations are appropriately specified and effectively implemented

- Interfacing with the assigned ER Program QA specialist on all quality-related matters

- Implementing continual, cost-effective quality improvements

- Performing surveillance of assigned project activities

\subsection{QUALITY ASSURANCE PROGRAM AND PROJECT REQUIREMENTS}

\subsubsection{Program Requirements}

The ER Quality Program will consist of the applicable Energy Systems QA policies, standards, and procedures and the ER QPP. The QPP will be approved by the Deputy Manager of ERWM Programs, the ER and PI\&A Division directors, the ER Quality manager, and the Energy Systems Quality director and will be executed throughout the ER Program organization. The following requirements apply.

- The ER QPP will be implemented to ensure that

- DOE, EPA, and Energy Systems QA requirenients are met;

- commonality and consistency in approach are applied across Energy Systems ER programs;

- roles and responsibilities of ER Program personnel, including internal and external interfaces, are clearly documented and understood; and

- the Energy Systems Environmental Surveillance Procedures Quality Control Program Manual (ESH/Sub/87/21706/1) (Energy Systems 1990) is utilized for all applicable activities. 
- QA plans will be prepared in accordance with NQA-1 for activities that do not require measuring and monitoring to be performed according to QAMS-005/80 (e.g., interim corrective measures).

- OA Project Plans (QAPjPs) will be developed for measuring and monitoring activities to implement the requirements of QAMS-005/80 and to evaluate the applicability of other quality requirements for the activity to be performed. When other Energy Systems organizations, contractors, and subcontractors perform work for the ER Program, the QAPjP may be prepared by that organization and reviewed or approved by the ER Program as defined in the statement of work or contract.

Figure 1.6 depicts the current hierarchy and relationship of the ER Program QPP, QAMS 005/80 QAPjPs, and other QA plans.

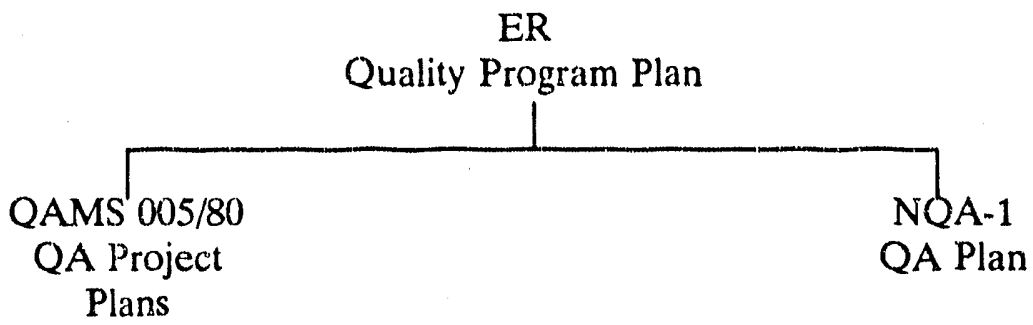

(Typical for each site)

Fig. 1.6. Hierarchy and relationship of ER Program quality assurance plans.

\subsubsection{Project Quality Assurance Plan Requirements}

QA plans are prepared for ER projects. The plans will be based on the applicable requirements of this ER QPP and will include any additional project-specific information needed to effectively manage and control the project. Two types of QA plans are used in the ER Program. Project plans meeting the requirements of QAMS 005/80 are required for each measuring and monitoring operation. These are normally prepared as part of the Sampling and Analysis Plan, which is required for a RCRA Facility Investigation or CERCLA Remedial Investigation/Feasibility Study activity. Major projects that do not include measuring and monitoring operations would not require a QAMS 005/80 QAPjP but will require development of a QA plan in accordance with the applicable NQA-1 elements listed in Fig. 1.1.

\subsubsection{NQA-1 specific quality assurance plans}

As stated above, QA plans will be prepared for major projects. The content of the project QA plan and the determination of the management controls to be applied to the project are to be defined in a graded and selective manner through evaluation of the technical activity to be performed and through assessment of the NQA-1 criteria that may be applicable to the technical activity. The content for these plans is prescribed in Energy Systems Quality 
Program Procedure ESP-QA-2.6, Quality Assurance Plans, which i: contained in Policy, Standards and Procedures Manual, Martin Marietta Energy Systems, Inc., Volume 4 (Energy Systems 1991b).

\subsubsection{QAMS-005/80 quality assurance project plans}

A QAPjP for a measuring and monitoring activity is a written document that presents in specific terms the policies, organization (where applicable), objectives, functional activities, and specific QA/QC activities designed to achieve the data quality goals of a specific project or continuing operation. The elements that must be included in a QAPjP are described in QAMS 005/80. They are listed in Table 1.2 .

Table 1.2 also identifies implementing procedures relative to the ER Program Quality Program and QAMS-005/80 elements. Some of the procedures required to implement elements of the QAPjP have been developed at the Energy Systems level. Procedures for other elements must be identified by the project team. (In cases where the project team is required to identify the procedure, Table 1.2 shows the procedure as "to be determined" in the "Implementing Procedures" column.) The requirements of those elements are further described within this document. The requirements also must be addressed by ER Program personnel in planning, implementing, and reporting environmental investigation, environmental restoration, and closure activities.

All QAMS-005/80 QA/QC requirements must be addressed in the QAPjP. In cases where specific $\mathrm{QA} / \mathrm{QC}$ requirements are addressed as an integral part of a technical work plan, it is only necessary to cite the page number where the requirements are located in the work plan on the QAPjP locator page. The QAPjP locator page must identify each of the elements required for the QAPjP and the section and pages that address the requirement. The locator page must be inserted immediately following the work plan table of contents. If a QAPjP element is not applicable to the work plan in question, the words "not applicable" should appear on the locator page in the appropriate section. Justification must be provided for identifying elements as "not applicable," and the justification must be approved by the program manager and QA specialist.

\subsection{Project description}

The purpose of the project description is to define the objectives or goals of the project and to describe the project design for obtaining the information needed to accomplish the goals. The project description shall include the following.

- An identification of the phase of the work and the specific objectives of the investigation

- A description (including a map) of the site location and size and important physical features of the site such as streams, ponds, roads, and buildings

- A chronological history of the uses of the site, including the types of chemical, radioactive, or hazardous materials known or suspected to have been used

- A brief summary of any previous sampling efforts and results

- A description of how the data will be used to address each project objective

- Anticipated beginning and completion dates 


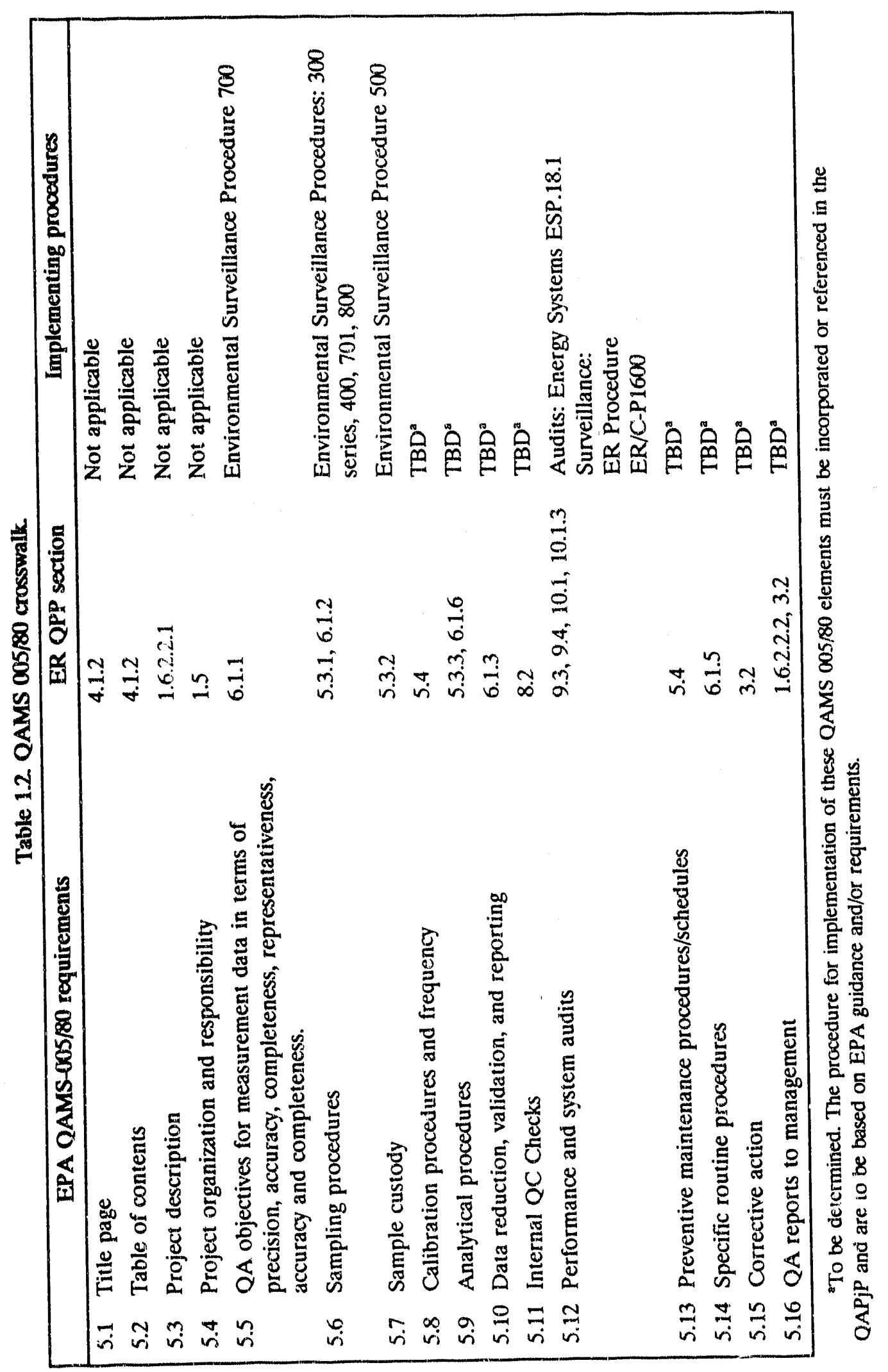




\subsubsection{Quality assurance reports to management}

Reports will be prepared for ER site program managers to provide evidence of project quality, cost, and schedule. Individuals responsible for preparing reports to management will be identified in the QAPjP. The reports to be prepared are as follows.

- Formal written reports. These reports will assess the performance of measurements systems and the quality of data.

- Audit and surveillance reports will be prepared and submitted by the person who conducts the audit or surveillance.

- Field observation reports will be prepared by the field sampling team.

- Site investigation reports will be prepared by the appropriate project team personnel.

- Reports on significant quality problems, recommended solutions, and corrective actions will be prepared by the ER project manager.

- Informal reports. These reports will be prepared by project personnel designated by the program manager, and the content will vary. Examples include identifying the status of

- permit approvals;

- document preparation and approvals;

- scheduled vs actual completions of field sampling and laboratory analyses;

- the accuracy and precision of field and laboratory analyses;

- the amount, type, and location of field-generated wastes; and

- actual vs anticipated costs and schedules. 


\section{TRAINING AND QUALIFICATION}

\section{GENERAL}

Program activities that affect quality are planned and accomplished under suitably controlled conditions. These controlled conditions include the use of appropriate equipment, establishment of suitable environmental conditions for accomplishing the activity, and assurance that prerequisites for the given activity have been satisfied.

Any special controls, processes, test equipment, tools, and skills necessary to attain the required quality are to be applied, and quality of the final product will be verified.

Personnel managing or performing activities affecting quality shall receive necessary indoctrination and performance-based training to ensure that suitable proficiency is achieved and maintained.

\subsection{TRAINING NEEDS ASSESSMENT}

Personnel to be indoctrinated or trained are identified on the basis of a "needs assessment," and the extent of indoctrination and training shall be commensurate with the (1) scope, complexity, and nature of the activity; and (2) education experience, and proficiency of the person.

\section{TRAINING PROGRAM IMPLEMENTATION}

Personnel shall be indoctrinated in the following subjects as they relate to a particular function: (1) general criteria, including applicable regulatory requirements and ER procedures governing their assigned activities; (2) this ER QPP; and (3) their specific job responsibilities and authority.

If needed, training shall be provided to (1) achieve initial proficiency, (2) maintain and enhance proficiency, and (3) adapt to changes in technology, methods, or job responsibilities. Performance-based training shall be provided when activities are specifically detailed in procedures and the level of quality obtained is directly proportional to the individual's ability to implement the procedure.

Quality assurance training may be conducted by either the EK quality staff, on-site training organizations, or ER site program managers after they have received the training themselves.

\section{RECORDS}

Records of the implementation of indoctrination and training may take the form of (1) attendance sheets, (2) training logs, or (3) personnel training records, and should be maintained as quality records by the ER training manager. 


\section{QUALITY IMPROVEMENT}

\subsection{GENERAL}

Continuous improvem is the goal of the ER Program. All employees are encouraged to offer suggestions regarding improvement of any processes utilized in accomplishing ER goals and objectives. The Energy Systems quality policy endorses a no-fault environment where personnel have the freedom ali responsibility to identify nonconforming activities, items, and procedures without fear of reprisal. Results of management-assessment and selfassessment activities will be continuously evaluated, and lessons learned will be applied to improve organizational performance by preventing problems and improving quality.

\subsection{CONTROL OF NONCONFORMING ITEMS}

This section describes the Quality requirements, responsibilities, and actions necessary to identify, report, segregate, dispose of, and control nonconforming items and services and to implement corrective actions. These corrective actions are necessary to prevent further processing, delivery, installation, or use of nonconforming items until the affected organizations are notified and the proposed technical disposition and corrective actions are approved. Controls will provide for identifying, documenting, evaluating, segregating (when practical), and disposing of nonconforming items or samples and for notifying affected organizations. All nonconformances will be reviewed by the ER Program whether the nonconformances were generated by the ER Program or by its subcontractors.

Additional Quality requirements for control of nonconforming items are identified in ESS-QA-15.0; ESI-QA-15.2; and ESS.ENV.1, Sect. 4.15, in Volume 4 of Policy Standards and Procedures Manual, Martin Marietta Energy Systems, Inc. (Energy Systems 1991b).

\subsection{CORRECTIVE ACIIONS}

Conditions adverse to quality which may adversely affect safety, health, the environment, or the reliability of ER activities and/or data must be promptly identified and corrected by authorized personnel. The root cause of significant conditions adverse to quality must be determined and corrected to prevent recurrence, and such conditions must be properly documented and reported to management in a timely manner.

Conditions that are adverse to quality are those that exceed predetermined acceptability limits, deviate from prescribed methods, fail to meet performance requirements or data quality objectives (DQOs), or fail to meet customer or regulatory requirements and expectations. Nonconformances, occurrences, management reviews, appraisals, audits, and problem investigations, as well as external appraisals, reviews, surveillances, etc., may identify conditions that require corrective action.

Additional Quality requirements for corrective actions and occurrence reporting are identified in ESS.16.0 and ESP-QA-16.1, which can be found in Volume 4 of Policy, Standards and Procedures Manual, Martin Marietta Energy Systems, Inc. (Energy Systems 
1991b), and ESS-OP-301, "Occurrence Reporting System," which is also found in that manual.

\subsection{EVALUATION OF CORRECTIVE ACTION ITEMS}

Any corrective action items identified against the ER Program will be reviewed for potential applicability to other elements of the program. Corrective action plans for those determined to be applicable to program elements other than where initially identified will be developed and implemented to address the extent of the identified condition, the root cause, and actions to prevent recurrence within the ER Program. Management shall ensure that proper focus is given to the adequacy of resources necessary to provide for timely resolution and correction of identified problems. 


\section{DOCUMENTS AND RECORDS}

\subsection{DOCUMENT CONIROL}

Document control is the process of ensuring that documents are reviewed for adequacy, ap roved for release by authorized personnel, and distributed to and used at the location where the prescribed activity is performed. Document control is essential to ER activities to ensure the precision and integrity of the sampling activities, laboratory analyses, and resulting conclusions and recommendations for each site. To fulfill this objective, the control system will provide for:

- identifying the documents to be controlled and their specific distribution;

- identifying the personnel responsible for preparing, reviewing, approving, and issuing documents;

- reviewing documents for adequacy, completeness, and correctness before they are approved and issued; and

- updating documents in a controlled and timely manner.

\subsubsection{Controlled Documents}

As a minimum, the following documents prepared by or for ER. will be controlled.

- ER Program QPP

- ER Program prosedures and instructions

- QA plans of all levels

- Health and safety plans

- Work plans

- Waste management plans

- Purchase orders and change orders

- Subcontractor documents defined in purchase orders

- Program service orders

- Project "baseline" schedules and cost estimates.

\subsubsection{QA Project Plan Document Control}

In addition to the general document control requirements listed in Sect. 4.1 , the following elements of the QAPjP will be addressed and controlled.

- An approval page will be included in the QAPJP sollowing the title page. As a minimum, the following signatures will be required to approve the document.

- the site or activity project manager

- the site program manager

- the QA specialist 
- A tille page will be included and controlled.

- The plan will include a table of contents with the following:

- an introduction that explains the omission of any of the QAMS 005/80 elements;

- a serial listing of each of the QAPJP elements shown in QAMS 005/80;

- a list of any appendixes required to augment the QAPjP as presented (i.e., standard operating procedures and so forth); and

- a iist of people, including the QA specialist, who will receive official copies of the QAPjP and subsequent revisions.

- A project description that addresses the requirements of Sect. 1.6.2.2.1 will be included in the QAPjP.

- Sampling procedures, sampling custody procedures, and analytical procedures will be included and controlled.

\subsection{QUALITY ASSURANCE RECORDS}

A QA records system will be designed, implemented, and enforced. Records may include physical samples or materials that retain or support data. QA records will include, but not be limited to, the documents listed as controlled in Sect. 4.1.2. ER Division directors and managers are responsible for identifying any $Q A$ records unique to their program activities which are in addition to those listed in this document.

The applicable QAPjP, design specifications, procurement documents, test procedures, operation procedures, or other documents will specify the records to be generated, supplied, or maintained by or for Energy Systems. QA records will be distinguished from project records by stamping or identification in the records index.

Records will be legible, accurate, and appropriately complete for the work accoinplished. The records will be indexed in a system that includes, as a minimum, record retention times and the location of the record within the record system. Records and/or indexing systerts will provide sufficient information to permit the identification of records with the items or activities to which they apply. Records generated as part of environmental, safety, and health data will be documented and retained in accordance with ESS.17.0 in Volume 4 of Policy, Standards and Procedures Manual, Martin Marietta Energy Systems, Inc. (Energy Systems 1991b).

Records will be stored in predetermined locations that meet the requirements of applicable standards, codes, regulatory agencies, and company policies. Records storage procedures will be prepared for both nonpermanent and permanent (lifetime) storage before records are stored.

Records will be stored in a manner approved by the ER organization or organizations that have identified the documents as a $Q A$ record. The method of storage will be one that prevents deterioration and provides for the safekeeping of the record. Storage will provide for retrieval of information according to the needs of the responsible organization. Additional requirements for $\mathrm{QA}$ records are identified in ESS 17.0. 


\section{WORK PROCESSES}

\subsection{INSTRUCTIONS, PROCEDURES, AND DRAWINGS}

Work processes affecting quality will be prescribed by and performed according to instructions, procedures, or drawings that are documented, controlled, reviewed, and approved (e.g., work plans, health and safety plans, etc.). Instructions, procedures, and drawings will contain quantitative or qualitative acceptance criteria for determining that the prescribed activities have been satisfactorily accomplished. Activities affecting quality that are performed for the ER Program by other divisions, plant organizations, contractors, or subcontractors may be performed in accordance with instructions, procedures, or drawings prepared by the organization doing the work. Responsibility for the adequacy of the procedures used to perform ER Program activities remains with the ER Program regardless of which organization prepares and issues the procedures. Therefore, as a minimum, the project team will review the procedures listed in the following paragraph before work is done. Specific requirements imposed by DOE and/or regulatory agencies will be adhered to, and all requirements will be clearly identified.

Procedures prescribing the following work processes will be included in each QAPJP.

- Sampling processes

- Sample custody

- Calibration of equipment used in obtaining samples and/or data

- Analytical processes

- Data reduction, validation and reporting

- Internal QC checks

- Audits and surveillances

- Preventive maintenance of sampling and data collecting equipment

- Data monitoring and installation of data monitoring equipment

- Specific, routine functions required to assess data precision and completeness

- Corrective action processes

Procedures prescribing work processes to be incorporated in QA plans not associated with measuring and monitoring activities will be identified in accordance with the requirements specified in Sect. 1.6.2.1.

Procedures are required to implement all of the requirements of this QPP.

\subsection{IDENTIFICATION AND CONTROL OF ITEMS}

This section addresses the control of quality-related items. Control will consist of the identification and documentation of such items. Identification of an item will be maintained either on the item itself or in documentation traceable to the item (e.g., chain-of-custody documentation). Identification requirements apply to instrumentation, equipmeitt, materials, and ER Program-generated wastes and samples (all items except paperwork). Item identification, whether on the item itself or in documentation, will be clear and legible. All equipment and instruments used in the program will be correctly identified and logged in the field logbook or the laboratory record book. Requirements for identifying, handling, storing, 
shipping, maintaining, inspecting, and documenting samples are described in the Environmental Surveillance Procedures Quality Program Manual (Kimbrough 1990).

\subsection{CONTROL OF PROCESSES}

Processes affecting the quality of items or services will be identified in QA plans and controlled by instructions, procedures, drawings, checklists, permits, or other appropriate means. Qualifications of personnel, procedures, and equipment will adhere to approved criteria and processes.

Each special process will be performed according to appropriate instructions. The conditions necessary to accomplish a process, including requirements, will be specified. For special processes not covered by existing codes and standards, or for situations where the quality requirements specified for an item exceed those of existing codes or standards, the instructions for that process will specify or reference the necessary procedures, equipment, and/or personnel levels and qualifications. Instructions for such special processes will become QA documents.

The requirements for procedures and equipment used in the field and in the laboratory are discussed in the Environmental Surveillance Procedures Quality Control Program Manual (Kimbrough 1990). All personnel using the procedures or equipment will adhere to those requirements. Additional Quality requirements for control of processes are identified in ESS.QA-9 in Volume 4 of Policy, Standards and Procedures Manual, Martin Marietta Energy Systems, Inc. (Energy Systems 1991b).

As a minimum, the field sampling and analytical processes will be controlled as indicated in the following paragraphs.

\subsubsection{Sampling Procedures}

Sampling procedures to be used on ER activity-specific projects will be selected from the Environmental Surveillance Procedures Quality Control Program Manual (Kimbrough 1990) or another Energy Systems procedure based on EPA standard sampling protocols. The ER QAPjP will be developed from the data specified in an ER preliminary assessment/site investigation or in other remedial investigation/feasibility study work plans or sampling plans. The sampling and analysis procedures to be selected, including sample preservation and holding times for the relevant chemical analyses and matrixes, will comply with applicable techniques selected from the following documents

- the Code of Federal Regulations

- federal and state regulations and criteria for chemicals

- EPA manuals and guidance documents

- EPA handbooks

- American Society for Testing and Materials standards

- American Public Health Association standards

- the Federal Register

Sampling operations will be performed so as to provide reliable information that meets the DQOs of the project. Procedures describing how field sampling activities actually are to 
be performed will be described or referenced in the QAPjP. As a minimum, procedures will address the following:

- ventilation, protection from extreme weather and temperatures, access to stable power, and provision for water and gases of required purity;

- equipment and equipment calibration and maintenance procedures;

- applicable personnel training requirements;

- the sequence of operations;

- holding times;

- solvents, reagents, and standards;

- the storage of solvents, reagents, and standards;

- decontamination and cleanliness control;

- personnel protection equipment;

- storage and disposal of wastes;

- documentation requirements;

- sample numbering and labeling requirements;

- reagent/standard preparation methods;

- field measurement methods for chemical, radiological, and physical parameters;

- corrective actions;

- data review, reduction and validation;

- reporting requirements;

- records management;

- control samples and sampling analysis;

- acceptance criteria for field activities;

- sampling equipment, techniques, containers, volumes, types, preservation methods, custody and shipment;

- frequency; and

- special conditions.

Personnel performing sampling activities will be trained and qualified according to a documented program. The QAPjP will identify training program requirements or reference the appropriate procedure.

\subsubsection{Sample Custody}

Sample custody will be documented on chain-of-custody forms to trace sample possession from the time of collection to final disposition according to the Environmental Surveillance Procedures Quality Control Program Manual (Kimbrough 1990).

The ER QAPjP will use the sample chain-of-custody procedure described in that manual. Sample custody will be documented throughout sample collection, shipping, analysis, and disposal. After collection and identification, samples requiring chemical analysis will be maintained under chain-of-custody procedures.

Each sample will be identified so that the location where it was obtained, the method used to obtain it, the date it was obtained, and the person(s) who obtained it can be traced. All wastes generated and handled at ER Program sites will be appropriately defined, physically identified, and appropriately segregated. All tests and analyses will be identified. The sample and methods used to obtain the data, the date of the tests performed, and the person(s) performing the test will be traceable. Laboratories that use limited-shelf-life solutions and 
reagents will be required to establish procedures to control those items to prevent use of a chemical for which the shelf life has expired.

A sample is considered to be under custody if any of the following conditions is met.

- It is actually in the possession of the person responsible for sample collection and chain of custody

- It is visible to the person who has taken possession

- It is secured by the person responsible for possession so that tampering can be detected

- It is in a secure area

\subsubsection{Analytical Procedures}

Procedures for test methods which describe how analyses are performed in the laboratory will be described or referenced in the QAPJP. Procedures approved by EPA will be used for preparing and analyzing samples, provided such procedures are available and appropriate to meet the specific DQOs of the project. Company or contractor standard operating procedures may be used if they describe the analysis exactly as it is described in published, EPA-approved procedures.

The selection of procedures(s) for each analyte will be based on the Energy Systems Environmental Surveillance Procedure, ESP-700. Subcontractor procedures will be reviewed for approval by the project team to ensure that their analytical methodologies comply with ESP-700. Some of the EPA-approved methods/procedures referenced in ESP-700 are as follows.

- Methods for Chemical Analysis of Water and Wastes (EPA-600/4-79-20) (EPA 1984)

- Test Methods for Evaluating Solid Waste: physical/chemical methods (SW-846) (EPA 1986)

- Prescribed Procedures for Measuring Radioactivity in Drinking Water (EPA 600/4-80-32) (EPA 1980)

If no EPA-approved procedure exists for analyzing a specific parameter, then the procedure to be used will be reviewed and approved by the project team and by appropriate technical personnel who are independent of the procedure preparer. Procedures will adhere to EPA technical and documentation requirements. The project team will confer with the appropriate regulatory agencies about the need for their review and approval of procedures that are not in accordance with existing EPA procedures.

If analytical laboratories are to provide reliable information, procedures and policies that address requirements beyond sample preparation and analysis must be implemented. Chapters 4.0-4.6 of SW-846 identify requirements for facilities, equipment and instrumentation, operating procedures, QA and QC procedures, QA reviews (audits and surveillances), and records. The QAPjP will describe or reference the procedures that implement the requirements of these chapiers in SW-846. Changes to such procedures will be controlled by the laboratory Quality program; those changes are subject to project team review. 
For each parameter analyzed, the sample preparation and analysis procedure(s), the revision used, and the detection limits will be listed in the QAPjP. Once the QAPjP is approved, these requirements will not be changed without the review and approval of the same organizations that approved the original plan.

The QAPjP will specify a method of ensuring that the required sample preparation and analysis methods are properly conveyed to the laboratory.

Personnel performing analyses will be trained and qualified according to a documented program. The QAPjP will identify the training program requirements or reference the appropriate procedure.

\subsection{CONTROL OF MEASUR NG AND TESTING EQUIPMENT}

The selection of measuring and testing equipment used for activities affecting quality will be controlled to ensure that it is of the type, range, accuracy, and tolerance required to determine whether items conform to specified requirements. Equipment selection will be based on the sampling and analysis methods described in the specific work activity and the Environmental Surveillance Procedures Quality Control Program Manual (Kimbrough 1990). When an organization other than the ER Division selects equipment, responsibility for the proper selection remains with the site ER program. However, the owner of the equipment is responsible for seeing that it is properly calibrated and that documentation of calibration to nationally recognized standards or methods is available to ER Program personnel.

The work plan will list the calibration standards to be used and the sources for each major measurement parameter, including all pollutant measurement systems. Equipment will be calibrated initially, and recalibrated at established intervals, against instruments certified as traceable to nationally recognized standards or methods.

The QAPjP will include a table listing the calibration procedure, schedule, and frequency for each type of equipment used for field sampling and analytical measurements. Preventive maintenance of measuring and testing equipment will be scheduled, and a list of critical spare parts will be developed for each specific work activity. The availability of spare parts will be determined before equipment is used to avoid down time because of an unavailability of parts.

\subsection{HANDLING, STORAGE, AND SHIPPING}

Samples collected and waste produced by ER activities will be controlled during handling, storage, and shipping to prevent damage and loss and to prevent deterioration of perishable materials and other environmental or safety insults. Handling, storage, and shipping of hazardous wastes will be coordinated with the applicable ER Waste Management Program manager and the applicable site Waste Management Division.

The shipping of all hazardous and nonhazardous wastes must comply with appropriate federal, state, and local regulatory standards and requirements. For materials such as hazardous chemicals and adioactive mixed wastes, special procedures may need to be developed to define requirements for generating, handling, storing, packaging, shipping, preserving, transferring, and receiving the wastes at the specific ER site involved. 


\section{DESIGN}

\subsection{DESIGN CONTROL}

Design control, as applied to the ER Program, is intended to define, control, and verify technical investigations, feasibility studies, remedial designs, and subsequent related activities. Design control measures are used to identify variables affecting the quality of those investigations, feasibility studies, and remedial designs and to identify and control variables affecting the quality of interrelated activities to ensure comparability.

Procedures for conducting technical investigations and other associated ER activities and the implementation of those procedures will be reviewed and approved for technical adequacy by qualified individuals other than those who wrote the procedures. Changes to procedures for conducting ER activities will be reviewed and approved by qualified individuals familiar with both the original procedure and the purpose of the activity. This is to ensure that the original purpose of the ER activity is fulfilled. Documentation and records providing evidence that ER activities were performed in accordance with this QPP will be collected, stored, and maintained as prescribed in documented and approved procedures and/or instructions.

Additional QA requirements for design control are identified in ESS-QA-3.0 in Volume 4 of Policy, Standards and Procedures Manual, Martin Marietta Energy Systems, Inc. (Energy Systems 1991b).

\subsubsection{Quality Assurance Objectives for Measurement Data}

Overall QA objectives for ER scientific investigations (e.g., field sampling activities and analyses of laboratory and other data) are identified to ensure that sufficient data of known quality are gathered to legally defend and support the study of environmental remedial alternatives. The DQOs described in the QAPjP should match the DQOs identified in the ER work plan if sampling is involved. These Quality objectives will be summarized in a table with a defined measurement objective for precision, accuracy, and completeness at the appropriate analysis level in accordance with EPA-540/G87/003A (OSWER Directive 9335.0-7B) (EPA 1987). Each associated DQO will be related to a method for determining the specific objective. Appropriate procedures will be identified, prepared, and used to ensure that all data will be gathered or developed for the intended use.

\subsubsection{Sampling Procedures}

The sampling procedures to be specified in ER QAPjPs will be selected to ensure that the ER work plan/sampling plan requirements are satisfied. This section of the QAPjP will present a table giving all sampling points, the sampling frequency, and the total number of samples plus replicates and field duplicates. A written procedure needs to be identified for each sampling activity. For additional information, see Sects. 5.3.1 and 5.3.2

\subsubsection{Analytical Procedures}

All analytical procedures will follow appropriate EPA standard methodology as contained in the Energy Systems Environmental Surveillance Procedures Quality Control Program Manual (Kimbrough et al. 1990). All samples should be identified in a summarized table along with 
the associated analytical procedure. Any analytical procedure that differs from a standard EPA method will be identified, along with the reasons for the specific deviation. The analytical procedures to be specified in the ER QAPjP are those identified in the ER preliminary assessment/site investigation or other remedial investigation/feasibility study work plans or sampling plans.

\subsubsection{Data Reduction, Validation, and Reporting}

The data reduction, validation, and reporting procedure to be specified in the ER QAPjP will be selected to ensure that the ER work plan/sampling plan data reduction, validation, and reporting requirements are satisfied. Data reduction, validation, and reporting will be done according to the approved laboratory standard operating procedure referenced in the work plan. The principle criteria used to validate data integrity during collection, required calculations, and reporting will be specified and described by a flow chart. Reporting units will be specified for all parameters, and a unique system to be used for flagging data will be specified. The appropriate ER project person responsible for data reduction, validation, and reporting will be identified. As a minimum, the procedure will describe:

- the data reduction scheme planned for collected data, including all equations used to calculate the concentration or value of the measured parameter and reporting units;

- the principal criteria that will be used to validate data integrity during collection and reporting of data;

- the methods used to identify and treat outliers

- the data flow or reporting scheme, from collection of raw data through storage of a validated concentration (a flow chart usually will be needed); and

- key individuals who will handle the data in this reporting scheme (If these have already been described under project organization and responsibilities, it need not be repeated here).

\subsubsection{Internal Quality Control Checks and Frequency}

The internal QC checks and frequency will be identified in the ER QAPjP. These checks usually consist of control samples, which may include blanks, duplicates, spikes, split samples, analytical standards, and reference materials. These different types of control samples can be used in different phases of the data collection process, beginning with sampling and continuing through transportation, storage, and analysis. The quantity of QC samples should be consistent with the level of quality indicated in Sect. 6.1.1 for each DQO. All data, calculations, and analyses will be checked by a technically qualified individua! who was not responsible for managing or performing the work. These checks will be made and documented to ensure that both technical and quality requirements have been satisfied.

\subsubsection{Specific Routine Procedures}

The specific routine procedures for assessing precision, accuracy, and completeness of each major measurement, as specified in the DQO table mentioned in Sect. 6.1.1, will be identified in the ER QAPjP. The procedures will include a detailed description of the equations to be used to calculate precision, accuracy, and completeness, along with a

description of the methods that were used to accumulate the data. These equations should 
be equivalent to those described in EPA-540/G87/003A (OSWER Directive 9335.0-7B) (EPA 1987).

\subsubsection{Automated Data-Processing Software}

Automated data-processing software (including modifications) used to produce or manipulate data for ER Program activities will be documented, verified and validated, approved, and controlled. The application of specific requirements will be prescribed in plans for software Quality which will describe the planned and systematic actions to be taken to ensure quality achievement. Software verification and validation activities shall ensure that (1) the software adequately and correctly performs all intended functions and (2) the software does not perform any unintended function that either by itself or in combination with other functions can degrade the entire system.

Software verification and validation activities will be planned and performed for each system configuration that may affect the software. The results of the software verification will be documented, and validation activities will be performed by individuals other than those who designed the software.

Additional Quality requirements for automated data-processing software are identified in ESS-QA-19 in Volume 4 of Policy, Standards and Procedures Manual, Martin Marietta Energy Systems, Inc. (Energy Systems 1991b) 


\section{PROCUREMENT}

\subsection{PROCUREMENT-DOCUMENT CONTROL}

Procurement-document control, as applied to the ER Program, is intended to ensure that applicable design bases, technical and quality requirements, and administrative controls are prepared, reviewed, and included or referenced in the procurement requisition packages prepared for quality-related activities.

Procurement-document control applies to documents supplied by organizations inside and outside Energy Systems. Documents such as statements of work and program service orders that are used to identify specific internal service requirements will be reviewed to ensure that necessary technical and quality requirements are included where applicable.

Procurement requisition packages for quality-related activities (to be prepared by ER Program personnel) will:

- define technical and quality requirements for items or services through documented statements of work, specifications, and/or references to national codes or standards;

- include drawings, inspection and test plans, acceptance criteria, and nonconformance reporting criteria;

- specify supplier technical and quality documentation to be submitted to ER or retained by the supplier;

- identify special inspection requirements for receiving, code inspecting, and supplier surveillance; and

- designate individuals or groups responsible for performing special inspection activities.

Completed procurement requisition packages that identify quality requirements must be reviewed and approved by designated ER Program technical and quality staff before the packages are submitted to Energy Systems Procurement.

Energy Systems Procurement administrative requirements for procurement requisition packages will include terms and conditions for:

- access to supplier facilities for performance monitoring,

- warranty protection,

- company acceptance criteria, and

- payment processes.

Energy Systems Procurement also will review procurement requisition packages for clarity, completeness, and the consistency of the legal obligations imposed on the supplier by the administrative, technical, and quality requirements that are specified.

Any changes or revisions to purchase orders or to procurement requisition packages that identify quality requirements are subject to further review and approval by ER Program technical and quality personnel and by Energy Systems Procurement. This requirement includes changes that may result from ER Program technical or quality reviews or from the Energy Systems Procurement administrative review. 
When review and revision of procurement requisition packages are completed, Energy Systems Procurement administrative, technical, and quality requirements will be incorporated in requests for proposals. Requests for proposals will be issued for bids; they will become purchase orders when a subcontract is awarded.

\subsection{CONTROL OF PURCHASED ITEMS AND SERVICES}

Purchased items and services that have the potential to affect health, safety; the environment, production, or schedules are controlled to ensure conformity with ER Program procurement requirements. Such control is provided through procurement planning, supplier evaluation and selection, and supplier performance evaluation and verification.

Control of purchased items and services applies to items and services supplied by organizations inside and outside Energy Systems. Purchase documents such as requests for proposals, specifications, drawings, statements of work, and program service orders will be reviewed to ensure that deliverables meet neccssary technical and quality requirements.

Procurement activities that are controlled will be planned. The plans will include documentation of the activities to be performed, the sequence of actions to be taken, the milestones for completion, and the assignment of responsibilities.

Supplier selection is based on a documented evaluation of the supplier's capability to conform to ER procurement requirements. The basis for selection may include a review of the supplier's past history, existing documentation, or an evaluation performed at the supplier's facility.

Techniques for evaluating and verifying supplier performance are included in ER procurement documents. Techniques used to ensure that suppliers understand procurementdocument requirements include, as applicable, bid proposal reviews, pre-award and post-award meetings, and reviews of alternatives and exceptions identified by suppliers. These techniques may include:

- supplier document reviews (including nonconformance reports),

- waivers,

- source surveillances,

- inspections or tests done in receiving, and

- certificates of conformance that must be submitted by suppliers.

In addition to the above requirements for control of purchased items and services, the ER Program will provide overall oversight of DOE prime contract ER activities according to DOE and Energy Systems contract DE-AC05-84OR21400, modification M066, paragraph H.17.

Additional Quality requirements for the control of processes are identified in ESS-QA-9.0 in Volume 4 of Policy, Standards and Procedures Manual, Martin Marietta Eneryy Systems, Inc. (Energy S,jtems 1991b). 


\section{INSPECTION AND ACCEPTANCE TESTING}

Field and laboratory work (e.g., sampling, drilling, and laboratory analysis) conducted in association with the ER Program will be inspected periodically. Inspections will be based on requirements for the given activity outlined in EPA guidance documents, the Environmental Surveillance Procedures Quality Control Program Manual (Kimbrough et al. 1990), site-specific investigation plans, and other available references. The site program manager will ensure that inspections are performed by qualified persons other than those who performed or directly supervised the work being inspected. Inspection results will be recorded in a field logbook, a daily logbook, and/or other relevant documents; they will verify that the characteristics of an activity are within specified limits. Corrective actions performed in response to inspection activities will be reported as outlined in Sect. 3.3, "Corrective Actions."

Additional Quality requirements for inspection are identified in ESS-QA-10.0 in Volume 4 of Policy, Standards and Procedures Manual, Martin Marietta Energy Systems, Inc. (Energy Systems 1991b).

\subsection{TEST CONTROL}

Tests required to verify that an item conforms to specific quality requirements or to demonstrate the satisfactory performance of an item will be planned, executed, and controlled. Site-specific work plans will identify the tests, requirements, acceptance criteria, and organizational responsibilities for performing tests. Tests will be performed by qualified persons using approved procedures that reference or include provisions to ensure that:

- prerequisites such as instrument calibration, special equipment maintenance and condition, and data acquisition needs are identified and completed before testing begins;

- proper instruments are available and used to perform the test;

- schedules are developed to provide time for monitoring test equipment and to ensure the availability of test personnel;

- suitable environmental conditions exist for conducting tests; and

- any special tests to be required for the laboratory chemical analysis of samples will be identified in the QAPjP.

Test requirements will be provided by the site program or project manager or by the subcontractor responsible for planning and conducting site activities (This excludes requirements for tests performed to verify that an item conforms to specific standards, or requirements for qualification tests to verify design adequacy). These requirements may also exist as part of existing design documentation. Additional Quality requirements for test control are identified in ESS-QA-11.1 and ESS.ENV.1, Sect. 4.11 in Volume 4 of Policy, Standards and Procedures Manual, Martin Marietta Energy Systems, Inc. (Energy Systems 1991b). 


\subsection{INSPECTION, TESTING, AND OPERATING STATUS}

This section covers the inspection, testing, and operating status of items used and wastes generated within the ER Program. To ensure that required inspections are performed and to ensure that items that have failed inspections and tests are not inadvertently installed, used, or operated, the inspection and testing status of items will be identified either on the items themselves or in documents traceable to the items. Status will be tracked through indicators such as physical location and tags, markings, stamps, inspection records, or other suitable means.

Field and laboratory QC procedures will be prepared which describe the methods used to establish and control the status of samples (e.g., soil, water, wastes, etc.). As a minimum:

- samples will be identified with a unique serial number;

- nonconforming samples will be identified with a unique nonconforming item tag, bag, or other marking (only designated Quality personnel will be permitted to remove nonconforming sample identiïcations);

- nonconforming samples will be segregated from acceptable samples;

- untested samples will be segregated from tested samples; and

- the sample custody procedural requirements of Sect. 5.3.2 will be an integral part of establishing and controlling the inspection, testing, and operating status of samples. 


\section{MANAGEMENT ASSESSMENT}

\subsection{SELF ASSESSMENT}

Self assessment is an integral part of the overall management assessment process. A DOE EM (Environmental Restoration and Waste Management) self-assessment management plan is being developed to implement the DOE self-assessment guidance document. This SelfAssessment Program requires definition of assessable units, development of measurable performance criteria, assessment of program activities against performance criteria, and routine reporting of assessment results. The key to the self-assessment program is continual, open ended assessment by the line management responsible for organization performance. This process is supplemented by assessments performed by individuals from the line organization who are independent from the activities being performed. The process also includes assessment results from organizations with oversight responsibilities.

The current Energy Systems Self-Assessment Program states that the principal self-assessment activities of line management are related to establishment of proper operations for implementing requirements of DOE orders and the law, establishment of how to implement such standards, and surveillance of organizational performance as compared with the requirements and standards.

Frequent line-management surveillances in the form of "walking your spaces with a specific purpose" are the primary mode of self-assessing and reinforcing standards of excellence.

Additional information regarding Energy Systems self assessment may be found in Description of Self-Assessment Program, Y/EX-43, Rev. 1 (Energy Systerns 1992a).

\subsection{SURVERLANCE}

In support of the Self-Assessment Program, surveillances will be conducted by ER Program personnel and subcontractors performing activities in support of ER Program goals and objectives. Surveillance is monitoring or observation to verify that requirements have been specified and that items or activities conform to the specified requirements. These surveillances are internal evaluations conducted and performed by line management personnel or their representatives to regularly assess the adequicy and effectiveness of the part of the Quality Program for which they are responsible.

Surveillances will be performed according to ER Division procedure ER/C-P1600, "Surveillance," which assigns responsibilities for identifying, scheduling, planning, and performing surveillance activities. The reporting of findings, observations, management responses, implementation and verification of corrective actions, and final closure of findings and negative observations will be tracked and documented.

Additional Quality requirements for surveillance are identified in ESP-QA-2.7 in Volume 4 of Policy, Standards and Procedures Manual, Martin Marietta Energy Systerms, Inc. (Energy Systems 1991b). 


\subsection{FIELD AUDTSS AND SURVEILLANCES}

Aidits and surveillances of field activities should consider the following:

- permits and document approvals;

- availability and use of procedures;

- personnel training and qualifications;

- equipment calibrations;

- site control and identification;

- pre-entry briefings;

- personnel protective equipment;

- health and hazardous material monitoring;

- sampling equipment cleanliness/decontamination;

- sample collection, preparation, and controls;

- waste controls and disposal; and

- corrective actions.

\subsection{ANALYTICAL LABORATORY AUDITS AND SURVEILLANCES}

Audits and surveillances of analytical laboratory activities should consider the following:

- permits and document approvals;

- the availability and use of procedures and analytical methods;

- personnel training and qualifications;

- equipment calibrations;

- laboratory quality controls;

- accuracy and precision;

- statistical control limits;

- laboratory method control samples;

- method blanks;

- matrix-specific bias;

- detection limits;

- personnel protective equipment;

- sample receipt, chain-of-custody practices, handling, scheduling, and storage;

- sample preparation;

- data reduction and validation;

- reporting;

- corrective actions; and

- waste controls and disposal.

\subsection{OPERATIONAL READINESS PROCESS}

An operational readiness process will be conducted to ensure that a given activity is ready for the next increment of work to proceed. This is done by identifying and minimizing the risks associated with mission success. The operational readiness process establishes and verifies the status of an activity and the degree of readiness for the next phase of work to begin or proceed. The ER Division site program manager is resporisible for identifying the activities that require application of the readiness process and for requesting a Readiness Review Board. The readiness process must result in an auditable record of the measures 
taken to determine and ensure that the activity is ready for the next increment of work to proceed.

Additional Quality requirements for the operational readiness process are identified in Energy Systems Policy Procedure GP-24 in Policy Standards and Procedures Manual, Martin Marietta Energy Systems, Inc. (Energy Systems 1991b).

\subsection{RISK ASSESSMENT}

Risk assessment is a human-health evaluation process that will be conducted as required to develop the risk information necessary to aid in decision making during each phase of environmental restoration. The risk assessment serves to:

- provide an analysis of baseline risks and determine the need for site action;

- determine the levels of contaminants that can remain on site without presenting possible risks to public health;

- compare potential health impacts of various remedial alternatives; and

- evaluate and document public health threats at sites.

The site program manager will ensure that risk assessments are effectively integrated with ER activities.

Additional requirements for risk assessment are identified in EPA guidance document EPA/540/1-89/002 (EPA 1989). 


\section{INDEPENDENT ASSESSMENT}

\subsection{AUDITS AND SURVEILLANCES}

Independent audits and surveillances will be scheduled, planned, performed, and documented. The requirements set forth in this document are delineated in Energy Systems Quality Procedures ESP-QA-2.7, Surveillance, and ESP-QA-18.1, Audits.

These audits are planned and documented activities performed to determine by investigation, examination, or evaluation of objective evidence the adequacy of and compliance with established procedures, instructions, drawings, and other applicable documents and the effectiveness of implementation.

Surveillance will be used to verify that requirements have been specified and that items or activities conform to the specified requirements.

A performance audit or surveillance is one that evaluates the effectiveness of the project in fulfilling its objectives. A system audit or surveillance is one that examines project activities to determine whether they comply with procedures and other applicable documents.

\subsubsection{Audits}

Audits of ER organizations or of organizations performing work for the ER Program will be performed early in a project to determine whether there is objective evidence that activities comply with procedures, instructions, drawings, and other documented requirements and that DQOs are clearly defined and implemented in plans, procedures, and other documentation. The requirement for conducting an audit of a laboratory may be waived by the ER Program Quality manager if the laboratory has been audited recently and no major unresolved quality problems have been found.

Audits will be performed by personnel who are independent of the organization or entity being evaluated. Audits will be performed according to Energy Systems Quality Procedure ESP-QA-18.1, Audits. The reporting of findings, observations, management and responses; implementation and verification of corrective action; and final closure of findings and negative observations will be tracked and documented.

\subsubsection{Surveillances}

Independent surveillances will be conducted in support of ER Program goals and objectives. They will be performed according to ER Division procedure ER/C-P1600, "Surveillance," which assigns responsibilities for identifying, scheduling, planning, and performing surveillance activities. The reporting of findings, observations, and management responses; implementation and verification of corrective action; and final closure of findings and negative observations will be tracked and documented.

\subsubsection{Field and Laboratory Audits and Surveillance}

Independent audit and surveillance of field and laboratory activities associated with the ER Program will be con' 1 cted. These independent evaluations will consider the same activities as identified in Sects. 9.3 and 9.4. 


\section{REFERENCES}

The ER Program Quality Program will conform to the current revisions of orders and standards referenced in the preceding sections and fully identified below.

ASME (American Society of Mechanical Engineers). 1989a. Quality Assurance Program Requirements for Nuclear Facilities, ASME NQA-1, New York.

ASME (American Society of Mechanical Engineers), 1989b. Quality Assurance Requirements for Nuclear Facility Applications, ASME NQA-2, New York.

Energy Systems (Martin Marietta Energy Systems, Inc.). March 1991a. Management Plan for the Oak Ridge Operations Environmental Restoration Program, DOE/ORO-931, Oak Ridge, Tennessee.

Energy Systems (Martin Marietta Energy Systems, Inc.). 1991b. Policy, Standards and Procedures Manual, Martin Marietta Energy Systems, Inc., Volume 4, Oak Ridge, Tennessee.

Energy Systems (Martin Marietta Energy Systems, Inc.). 1992a. Description of Self -Assessment Program. Y/EX-43, Rev. 1, Oak Ridge Y-12 Plant.

Energy Systems (Martin Marietta Energy Systems, Inc.). 1992b. Quality Program Plan, Y/QD-15 Rev 0, Oak Ridge, Tennessee.

EPA (U.S. Environmental Protection Agency). 1980. Prescribed Procedures for Measuring Radioactivity in Drinking Water, EPA 600/4-80-032, Washington, D.C.

EPA (U.S. Environmental Protection Agency). 1984. Methods for Chemical Analysis of Water and Wastes, March 1984 update, EPA-600/4-79-20, Washington, D.C.

EPA (U.S. Environmental Protection Agency). November 1986. Test Methods for Evaluating Solid Waste, 3 Ed., EPA SW-846.

EPA (U.S. Environmental Protection Agency). March 1987. Data Quality Objectives for Remedial Response Activities, EPA 540/G-87/003A, OSWER Directive 9335.0-7B, Office of Emergency and Remedial Response, Washington, D.C.

EPA (U.S. Environmental Protection Agency). October 1988. Guidance for Conducting Remedial Investigations and Feasibility Studies Under CERCLA, Interim Final, EPA/540/G-89/004, Office of Solid Waste and Emergency Response (OSWER) Directive 9355.3-01, Washington, D.C.

EPA (U.S. Environmental Protection Agency). 1989a. RCRA Facility Investigation (RFI) Guidance, EPA 530/SW-89-031, Office of Solid Waste and Emergency Response (OSWER.) Directive 9502.00-6D, Washington, D.C. 
EPA (U.S. Environmental Protection Agency). December 1989b. Risk Assessment Guidance for Superfund, Volume I: Human Health Evaluation Manual (Part A), EPA/540/1-89/002, Office of Emergency and Remedial Response, Washington, D.C.

Kimbrough, C. W., L. W. Long, and L. W. McMahon. January 1990. Environmental Surveillance Procedures Quality Control Program Manual, Revision 1, ESH/Sub/87/21706/1, Martin Marietta Energy Systems, Inc., Oak Ridge National Laboratory.

Stanley, T. W. and S. S. Verner. February 1983. Interim Guidelines and Specifications for Preparing Quality Assurance Project Plans, EPA-600/4-83-004, QAMS-005/80, Office of Exploratory Research, U.S. Environmental Protection Agency, Washington, D.C. 


\section{INTERNAL DISTRIBUTION}

1. S. M. Adams

2. J. M. Asher

3. L. V. Asplund

4. J. W. Autry

5. M. B. Baer

6 L. D. Bates

7. D. E. Beck

8. C. W. Beeks

9. D. T. Bell

10. D. F. Bennett

11-12. H. D. Bewley

13. S. C. Bieneik

14. B. G. Blaylock

15. W. R. Brown, Jr.

16. V. J. Brumback

17. S. N. Burman

18. J. C. Campbell

19. Charles Clark

20. L. B. Cobb

21-26. J. S. Colley

27. K. W. Cook

28. R. B. Cook

29. E. T. Collins

30. D. G. Cope

31. T. Cothran

32. D. Davenport

33. N. W. Durfee

34. J. A Early

35. T. O. Early

36. J. T. Etheridge

37. C. A. Farnsworth

38. R. E. Fernstermaker

39. C. J. Ford

40. H. R. Gaddis

41. S. B. Garland

42. P. L. Goddard

43. C. D. Goins

44. J. L. Greene

45. J. T. Grumski

46. P. J. Halsey

47. T. L. Hatmaker

48. J. L. Haymore

49. G. J. Haynes

50. N. A. Hefty

51. M. M. Heiskell

52. R. M. Hill, Jr.
53. J. A. Hodgins

54. F. O. Hoffman

55. R. K. Holmes

56. L. A. Hook

57. C. G. Hudson

58. D. D. Huff

59. L. P. Hull

60. L. D. Hyde

61. G. James

62. L. L. Kaiser

63. K. W. Keever

64. C. W. Kimbrough

65. B. L. Kimmel

66. A. F. Kiriluk

67. T. M. Koepp

68. A. J. Kuhaida

69. J. A. Lea

70. S. M. Leone

71. N. A. Luedtke

72. L. E. May

73. A. F. McClanahan

74. G. D. Mencer

75. D. G. Miller

76. J. Q. Miller

77. N. J. Montgomery

78. K. M. Nelson

79. H. C. Newsom

80. T. J. Newsom

81. J. D. Noblit

82. M. J. Norris

83-84. P. T. Owen

85. G. J. Pardue

86. J. G. Parrott

87. J. S. Phillips

88. G. A. Plante

89. G. M. Powers

90. P. N. Rader

91. L. O. Ramsett, Paducah

92. T. G. Ramsey

93. J. Reafsnyder

94. W. D. Rideout

95. G. E. Rymer

96. P. A. Schrandt

97. B. J. Scott

98. D. E. Searle

99. L. G. Shipe 
100. J. K. Siberell

101. R. H. Snyder

102. M. L. Sollenberger

103. J. V. Spence

104. R. J. Spence

105. W. J. Spetnagel

106. A. M. Stanley

107. T. D. Taylor

108. W. W. Thompson, Jr.

109. T. S. Tison

110. K. S. Turner

111. G. L. Underberg

112. J. H. Vanderlan

113. S. D. Van Hoesen

114. C. J. Vanineter

115. L. D. Voorhees

116. B. D. Walker

117. C. S. Walker
118. K L. Walker

119. A. E. Walzer

120. J. S. Watson

121. D. R. Watkins

122. S. C. Wells

123. D. C. White

124. R. K. White

125. L. M. Whitehead

126. A. S. Will

127. P. A Williams

128. M. A. Woody

129. Central Research Library

130. K-25 Technical Library

131. Y-12 Technical Library

132-136. ER Document Management Center-RC

137. Y-12 Document Center

138. ORNL. Laboratory Records

\section{EXTERNAL DISTRIBUTION}

139. G. W. Bodenstein, DOE Oak Ridge Field Office, P.O. Box 2001, Oak Ridge, TN 37831-8541

140. V. F. Boston, DOE Oak Ridge Field Office, P.O. Box 2001, Oak Ridge, TN 37831-8541.

141. D. M Carden, DOE Oak Ridge Field Office, P.O. Box 2001, Oak Ridge, TN 37831-8541

142. Division Office of Quality Assurance, DOE Oak Ridge Field Office, P. O. Box 2001, Oak Ridge, TN 37831-8541

143. D. W. Dollins, DOE Oak Ridge Field Office, Paducah, Kentucky, Building C100, DOE Office

144. R. C. Edwards, DOE Oak Ridge Field Office, Paducah, Kentucky, Building C100, DOE Office

145. C. S. Gist, DOE Oak Ridge Field Office, P.O. Box 2001, Oak Ridge, TN 37831-8541

146. S. L. Lankford, DOE Oak Ridge Field Office, P.O. Box 2001, Oak Ridge, TN 37831-8541

147. T. A. Larkin, DOE Oak Ridge Field Office, P.O. Box 2001, Oak Ridge, TN 37831-8541

148. R. W. Meehan, Department of Energy Portsmouth Site Office

149-150. R. L. Nace, Branch Chief, Nonenrichment Facilities, Oak Ridge Program Division, Office of Eastern Area Programs, Office of Environmental Restoration, EM-423, Trevion 2, U.S. Department of Energy, Washington, DC 20585

151. D. G. Page, DOE Oak Ridge Field Office, P.O. Box 2001, Oak Ridge, TN 37831-8541

152. S. P. Riddle, DOE Oak Ridge Field Office, P.O. Box 2001, Oak Ridge, TN 37831-8541

153. J. D. Rothrock, DOE Oak Ridge Field Office, P.O. Box 2001, Oak Ridge, TN 37831-8541

154-163. R. C. Sleeman, DOE Oak Ridge Field Office, P.O. Box 2001, Oak Ridge, TN 37831-8541

164. R. R. Stone, Radian Corporation, 120 S. Jefferson Circle, Oak Ridge, TN 37830

165. J. T. Sweeney, DOE Oak Ridge Field Office, P.O. Box 2001, Oak Ridge, TN 37831-8541

166. D. W. Swindle, Radian Corporation, 120 S. Jefferson Circle, Oak Ridge, TN 37830

167-168. H. M. Thron, Chief, Enrichment Facilities, Oak Ridge Program Division, Office of Eastern Area Programs, Office of Environmental Restoration, EM-423, Trevion 2, U.S. Department of Energy, Washington, DC 20585

169. M. A. Travaglini, DOE Oak Ridge. Field Office, P.O. Box 2001, Oak Ridge, TN 37831-8541

170. T. J. Wheeler, Department of Energy, Oak Ridge Operations, P.O. Box 2001, Oak Ridge, TN 37831.8540

171-172. Office of Scientific and Technical Information, P.O. Box 62, Oak Ridge, TN 37831 


\section{$\Gamma$}
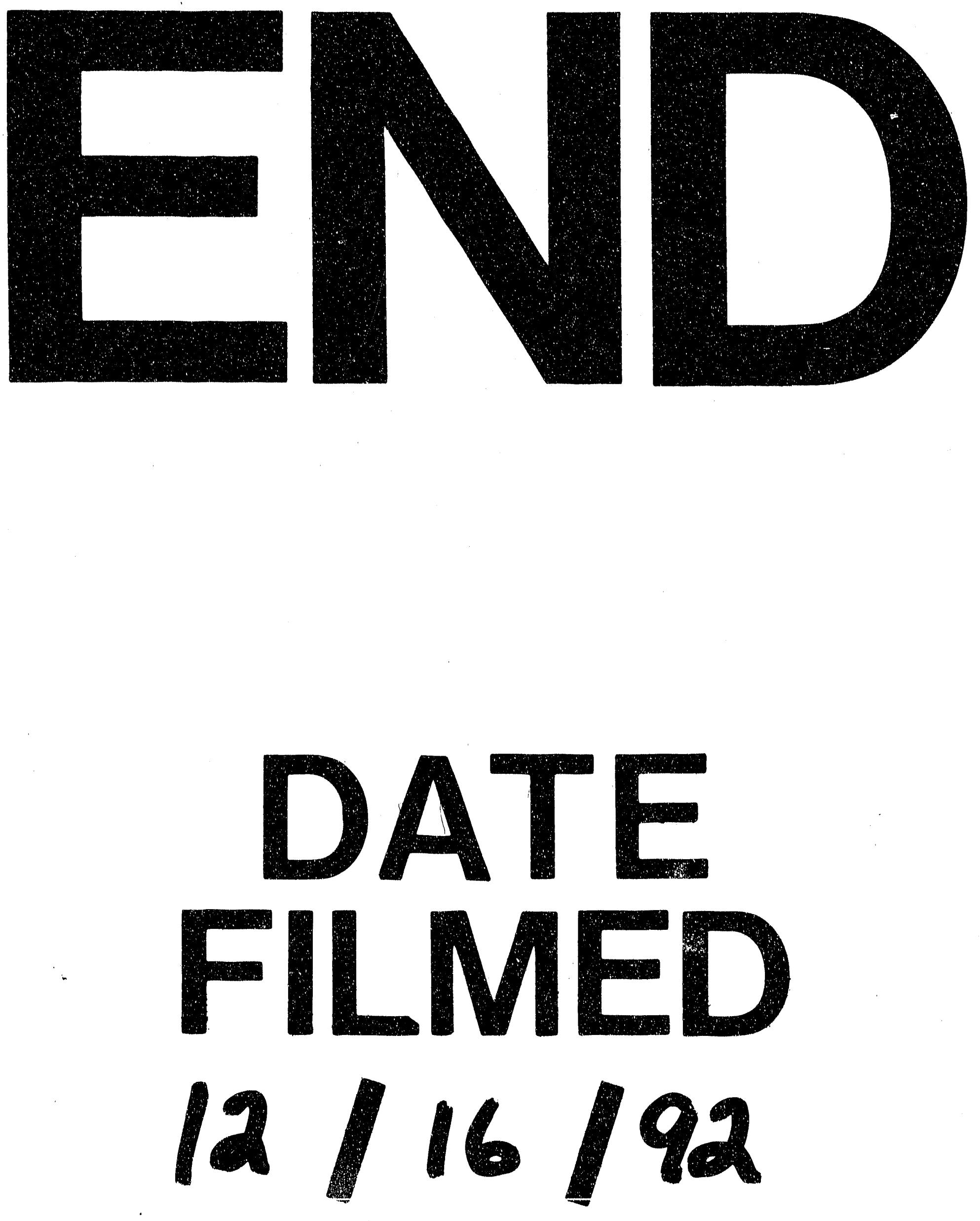
